Special Issue on

Public Sector Productivity and Competitiveness

Public Enterprise

Volume 24, Issue 1, 2019

https://doi.org/10.21571/pehyj.2019.2401.03

\title{
Sustainable Land Management: The Forgotten Pillar of Competitiveness
}

\author{
Emigdio Alfaro \\ CENTRUM Católica Graduate Business School (CCGBS), Lima, Peru \\ Pontificia Universidad Católica del Perú (PUCP), Lima, Peru
}

Received April 2018; Revised March 2019; Accepted March 2019

\begin{abstract}
Generally, frameworks for environmental interventions are focused only on the fight against climate change, the conservation of biological diversity, and the fight against desertification, land degradation, and drought, but not as a whole with indicators which could guide the attainment of better results for projects in diverse countries and organizations. A review of existing literature shows that there are no integrated frameworks for interventions regarding sustainable land management projects. The purpose of the present study is to propose an integrated framework for interventions of sustainable land management in countries with a national, regional, and local approach to contributing to their competitiveness and organizations. The proposed integrated framework for interventions contains objectives and indicators for managing the fight against climate change, the conservation of biological diversity, and the fight against desertification, land degradation, and drought, with a holistic approach. As a result, the Sustainable Land Management's Integrated Framework for Interventions (SLMIFI) is presented. SLMIFI could guide relevant governmental and non-governmental organizations in their efforts to develop and manage environmental projects with a focus on sustainable land management. Finally, the inclusion of the sustainable land management of countries as a pillar in the construction of competitiveness indexes is recommended, together with various managerial suggestions and guidelines for future research.
\end{abstract}

Keywords: Sustainable land management, competitiveness, SLMIFI, climate change, biological diversity, desertification and drought.

Reference to this paper should be made as follows: Alfaro, E. (2019). Sustainable Land Management: The Forgotten Pillar of Competitiveness. Public Enterprise, 24(1), 30-67. 


\section{Introduction}

Although sustainable land management is one of the most important topics for the world economy, as of now, this theme has not been included as part of the components of the global indexes related to competitiveness. In this sense, Schwab (2017) explained the emerging consensus about the fact that "economic growth once again needs to focus more on human well-being" (p. vii) and pointed out that "such human-centric economic progress is multidimensional by nature-it is broad based by benefitting the vast majority of people, environmentally sustainable, and equitable in terms of creating opportunities for all and not disadvantaging future generations" (p. vii). Schwab (2017) also indicated that: "In this new context, competitiveness remains an important contribution to the broader goal of human-centric economic progress by creating the resources needed for increased well-being, including better education, health, and security, and higher per capita income" (p. vii). Then, the sustainable land management (SLM), which is considered as "a promising solution to land restoration, mitigation of climate change, and resilience of rural population to external shock" (Maisharou, Chirwa, Larwanou, Babalola, \& Ofoegbu, 2015, p. 1) and includes issues and solutions related to climate change, biological diversity, desertification, land degradation, and drought has become one of the most important issues for improving the competitiveness of the countries and their organizations; however, this pillar seems to have generally been forgotten in the construction of global indexes related to competitiveness.

The officials of the United Nations have created formal organizational structures for managing the fight against climate change, the conservation of biological diversity, and the fight against desertification and drought, through the United Nations Framework Convention on Climate Change - UNFCCC (United Nations, 1992a), United Nations Convention on Biological Diversity - UNCBD (United Nations, 1992b), and the United Nations Convention to Combat Desertification - UNCCD (United Nations, 1994), respectively. Although these global efforts have been vital to improve the environmental management of the countries, the separate creation of these formal organizational structures has resulted in the actors and stakeholders associated with these issues to act through separate efforts without being able to achieve the respective management synergies at the levels of the national, regional, and local governments, as well as at the level of civil society, with the corresponding reduction of the competitiveness of the countries and their organizations.

This situation is even more critical when considering that, in practice, the actors and stakeholders involved in the development of the actions of the three conventions mentioned above are one and the same. In different countries worldwide, in the national government and in the regional and local governments, there are generally separate formal organizational structures to address these issues. In addition, it is common to find three separate national strategies for the purposes of the three conventions corresponding to the United Nations. In view of the above, it becomes necessary to integrate efforts and achieve management synergies to make the most of available resources and to achieve the proposed global goals, improving the competitiveness of the countries and their organizations.

\section{Background of the Problem}

The lack of synergies in the actions related to the three conventions mentioned in previous section for a real sustainable land management is a global issue. Regarding the separate budget for actions related to the climate change and the biodiversity in the European Union (EU), Kettunen (2018) explained that "even though the financial allocations from the EU development budget signal an ongoing and even slightly increasing commitment to biodiversity, they remain limited in comparison to the efforts related to climate 
change" (p. 159). About the objectives and actions of the EU's Biodiversity Strategy for 2020 and the lack of synergies in the actions related to the three conventions in the EU, Kettunen (2018, p. 149) explained:

These objectives and actions require coordination with other EU policy sectors including trade and development cooperation. Furthermore, synergies between the EU action on biodiversity and other environmental measures such as climate mitigation and adaptation are a key element of the Biodiversity Strategy. This includes the EU's promise to promote enhanced cooperation between the CBD and the UN climate change and desertification conventions to yield mutual benefits (European Commission 2011).

About the multilateral conventions, Biedenkopf, Torney, and Adelle (2018) explained that: "The EU has been a driving force and demander of multilateral conventions on a broad range of issues, including chemicals, climate change, biodiversity, desertification, ozone-depleting substances, aviation and waste" (p. 338). Biedenkopf et al. (2018) also explained that: "Yet, it is important to note that this is a relative assessment compared to other jurisdictions' levels of ambition" (p. 338) and that: "It does not necessarily mean that the EU's level of ambition is sufficient to achieve the goals that were set by the various international agreements" (p. 338).

Diverse authors explained about the effects of the climate change in the USA (Abatzoglou \& Williams, 2016), EU (Dupont, Oberthür, \& Biedenkopf, 2018), Ghana (Adelle, Delputte, De Roeck, \& Nicholson, 2018), Latin America and the Caribbean (Rodríguez De Luque, González, Gourdji, Mason-D’Croz, Obando-Bonilla, Mesa-Diez, \& Prager, 2016), and Kenya (Bryan, Ringler, Okoba, Koo, Herrero, \& Silvestri, 2013). About the effect of climate change on the forest fire area in the USA, Abatzoglou and Williams (2016) estimated that "human-caused climate change contributed to an additional 4.2 million ha of forest fire area during 1984-2015, nearly doubling the forest fire area expected in its absence" ( $p$. 11770). Dupont, Oberthür, and Biedenkopf (2018) indicated that: "Economic crisis and increasing domestic opposition to climate policy, rooted in fossil fuel interests and populism, have heightened internal divisions leading to less ambitious domestic policy" (p. 120) and that: "This, in turn, affects the perception of the EU as a leading actor on climate change internationally and its ability to shape effectively climate governance beyond its borders" (p. 120). Dupont et al. (2018) also explained that: "Furthermore, external contexts, including the rise of the emerging powers and developments in US politics and US-Chinese relations, have limited the EU's international climate role" (p. 120) and pointed out that: "Under these challenging circumstances, the EU has demonstrated significant adaptive capacity so as to remain an influential player in international climate politics" (p. 120). Additionally, Adelle, Delputte, De Roeck, and Nicholson (2018, p. 92) explained the effects of climate change in Ghana, as follows:

Ghana offers interesting insights in this regard, since the country is particularly vulnerable to the effects of climate change. Ghana is already starting to experience more extreme weather conditions, desertification, changing rainfall patterns and more rapid coastal erosion. Moreover, Ghana also suffers from a high degree of socio-economic vulnerability, due to the fact that its economy is still mainly based on sectors that can be considered climate sensitive (e.g. agriculture and forestry) (DARA 2012).

Rodríguez De Luque et al. (2016) modeled the socio-economic impacts of climate change in Latin America and the Caribbean for the period 2020-2045. The results of their study revealed that "the growth of corn and beans production would fall significantly in Nicaragua, El Salvador, Guatemala, Honduras, Colombia, Venezuela and Brazil, and rice and wheat would decline significantly in Brazil, Argentina and 
Uruguay" (p. 12) and that "climate change has the capacity to partially curb the progress in food security in the region, due to its negative effects on food availability" (p. 12). Additionally, Bryan, Ringler, Okoba, Koo, Herrero, and Silvestri (2013) indicated that: "Increasing poverty, dependence on low-input agricultural production, and rapid population growth are critical challenges facing Kenya" (p. 162) and explained that "Climate change will further exacerbate these problems unless investments in agriculture and rural development increase, particularly those targeted towards strategies that provide multiple benefits to the most vulnerable smallholder producers" (p. 162).

About the land degradation, Critchley and Radstake (2017) explained that the results of the FAO's Global Land Degradation Information System study of land degradation revealed that " $25 \%$ of the world's terrestrial surface was highly degraded or degrading, and a further $8 \%$ was moderately degraded or degrading" (p. 6). "However, on the positive side, 10\% was found to be improving (FAO 2010b): these improvements have surely stemmed, at least partially, from investment and education programs based on the principles of sustainable land management" (p. 6). About the impacts of pesticides on biodiversity, Dudey, Attwood, Goulson, Jarvis, Bharucha, and Pretty (2017) explained that: "Despite new evidence, conservation organizations have tended not to fully recognize the impacts of pesticides on biodiversity, and current conservation strategies pay little heed to addressing this threat" (p. 449) and that: "A comprehensive suite of strategies are required to reduce and rationalize pesticide use and mitigate risks to species conservation" (p. 449).

With respect to the water availability in People's Republic of China (PRC), Critchley and Radstake (2017) indicated that: "Water will be an increasingly severe limitation to production in Asia. For example, the PRC, with $20 \%$ of the world's population, has only around $7 \%$ of global freshwater supplies-yet currently has to produce for this number on just $10 \%$ of the global land area (The Economist 2013b)" (p. 14). Critchley and Radstake (2017) also explained that "Countries in Asia are taking the lead in implementing green growth by reforming economic incentives, promoting a more inclusive and adaptive governance, and pursuing and investing in green strategies and policy reforms that help align economic growth strategies with the objective of sustainable development (ADB 2012)" (p. 4). With respect to the desertification in Latin America and the Caribbean, the officials of the United Nations (2018) explained that "UNDP/EU (2015) estimates that, in Latin America and the Caribbean, approximately $60 \%$ land is arid and more than 300 million hectares of agricultural land are desert, approximately $20 \%$ of the arable land" (p. 25) and that "IFAD (2010) estimates that $50 \%$ of agricultural land in the region will be subject to desertification by 2050” (p. 25).

As can be appreciated from the above, there are not sufficient synergies in the actions related to the three conventions for the interventions on sustainable land management and the impact of this lack of synergies is increasing the effects of desertification, land degradation, drought, climate change, and the lack of conservation of biodiversity on the competitiveness of the countries and their organizations. This situation originates from the highest levels of management structures of the conventions and is replicated in the governments and the civil society internationally. It is, thus, necessary to approach the problem in a holistic manner.

\section{Problem Statement}

After the literature review, there were not found previous studies that proposed an integrated framework for interventions on sustainable land management at the national, regional, and local government levels, a situation which reduces the competitiveness of the countries and their organizations. 


\section{Purpose of the Study}

The purpose of the present study was to advance an integrated framework for interventions on sustainable land management of the countries with a national, regional, and local approach for contributing to the competitiveness of the countries and their organizations.

\section{Theoretical Framework}

\section{Competitiveness: Definition, Pillars, and Components}

Schwab (2017) explained that the specialists of the World Economic Forum defined competitiveness as "the set of institutions, policies, and factors that determine the level of productivity of an economy, which in turn sets the level of prosperity that the economy can achieve" (p. 11). Schwab (2017) also explained the pillars of competitiveness according to the methodology proposed in the Global Competitiveness Index 2017-2018 Report; these pillars are presented in Table 1. Additionally, Schwab (2017) indicated that although the results of the 12 pillars of competitiveness are reported separately, "it is important to keep in mind that they are not independent: they tend to reinforce each other, and a weakness in one area often has a negative impact in others" (p. 319). Schwab (2017, p. 43) also detailed the components of the 12 pillars as follows:

Table 1

The 12 Pillars of the Global Competitiveness Index 2017-2018 Report (Schwab, 2017)

\begin{tabular}{|c|c|c|}
\hline $\mathbf{N}$ & Pillar & Concept \\
\hline 1 & Institutions & $\begin{array}{l}\text { "The institutional environment of a country depends on the } \\
\text { efficiency and the behavior of both public and private } \\
\text { stakeholders" (p. 317). }\end{array}$ \\
\hline 2 & Infrastructure & $\begin{array}{l}\text { "Extensive and efficient infrastructure is critical for ensuring the } \\
\text { effective functioning of the economy" (p. 317). }\end{array}$ \\
\hline 3 & $\begin{array}{l}\text { Macroeconomic } \\
\text { Environment }\end{array}$ & $\begin{array}{l}\text { "The stability of the macroeconomic environment is important for } \\
\text { business and, therefore, is significant for the overall } \\
\text { competitiveness of a country" (p. 318). }\end{array}$ \\
\hline 4 & $\begin{array}{l}\text { Health and } \\
\text { Primary } \\
\text { Education }\end{array}$ & $\begin{array}{l}\text { "A healthy workforce is vital to a country's competitiveness and } \\
\text { productivity" (p. 318). }\end{array}$ \\
\hline 5 & $\begin{array}{l}\text { Higher } \\
\text { Education and } \\
\text { Training }\end{array}$ & $\begin{array}{l}\text { "Quality higher education and training is crucial for economies } \\
\text { that want to move up the value chain beyond simple production } \\
\text { processes and products" (p. 318). }\end{array}$ \\
\hline 6 & $\begin{array}{l}\text { Goods Market } \\
\text { Efficiency }\end{array}$ & $\begin{array}{l}\text { "Countries with efficient goods markets are well positioned to } \\
\text { produce the right mix of products and services given their } \\
\text { particular supply-and-demand conditions, as well as to ensure that } \\
\text { these goods can be most effectively traded in the economy" (p. } \\
318 \text { ). }\end{array}$ \\
\hline
\end{tabular}




\begin{tabular}{|c|c|c|}
\hline 7 & $\begin{array}{c}\text { Labor Market } \\
\text { Efficiency }\end{array}$ & $\begin{array}{l}\text { "The efficiency and flexibility of the labor market are critical for } \\
\text { ensuring that workers are allocated to their most effective use in } \\
\text { the economy and provided with incentives to give their best effort } \\
\text { in their jobs" (p. 318). }\end{array}$ \\
\hline 8 & $\begin{array}{c}\text { Financial } \\
\text { Market } \\
\text { Development }\end{array}$ & $\begin{array}{l}\text { "An efficient financial sector allocates the resources saved by a } \\
\text { nation's population, as well as those entering the economy from } \\
\text { abroad, to the entrepreneurial or investment projects with the } \\
\text { highest expected rates of return rather than to the politically } \\
\text { connected" (p. 318). }\end{array}$ \\
\hline 9 & $\begin{array}{c}\text { Technological } \\
\text { Readiness }\end{array}$ & $\begin{array}{l}\text { "The technological readiness pillar measures the agility with } \\
\text { which an economy adopts existing technologies to enhance the } \\
\text { productivity of its industries, with specific emphasis on its } \\
\text { capacity to fully leverage information and communication } \\
\text { technologies (ICTs) in daily activities and production processes } \\
\text { for increased efficiency and enabling innovation for } \\
\text { competitiveness" (p. 318). }\end{array}$ \\
\hline 10 & Market Size & $\begin{array}{l}\text { "The size of the market affects productivity since large markets } \\
\text { allow firms to exploit economies of scale. Traditionally, the } \\
\text { markets available to firms have been constrained by national } \\
\text { borders" (p. 319). }\end{array}$ \\
\hline 11 & $\begin{array}{c}\text { Business } \\
\text { Sophistication }\end{array}$ & $\begin{array}{l}\text { "Business sophistication concerns two elements that are } \\
\text { intricately linked: the quality of a country's overall business } \\
\text { networks and the quality of individual firms' operations and } \\
\text { strategies" (p. 319). }\end{array}$ \\
\hline 12 & Innovation & $\begin{array}{l}\text { "Innovation is particularly important for economies as they } \\
\text { approach the frontiers of knowledge, and the possibility of } \\
\text { generating more value by merely integrating and adapting } \\
\text { exogenous technologies tends to disappear. In these economies, } \\
\text { firms must design and develop cutting-edge products and } \\
\text { processes to maintain a competitive edge and move toward even } \\
\text { higher value-added activities" (p. 319). }\end{array}$ \\
\hline
\end{tabular}

1. First pillar: Institutions. Components: property rights, intellectual property protection, diversion of public funds, public trust in politicians, irregular payments and bribes, judicial independence, favoritism in decisions of government officials, wastefulness of government spending, burden of government regulation, efficiency of legal framework in settling disputes, efficiency of legal framework in challenging regulations, transparency of government policymaking, business costs of terrorism, business costs of crime and violence, organized crime, reliability of police services, ethical behavior of firms, strength of auditing and reporting standards, efficacy of corporate boards, protection of minority shareholders' interests, and strength of investor protection. (p. 322)

2. Second pillar: Infrastructure. Components: quality of overall infrastructure, quality of roads, quality of railroad infrastructure, quality of port infrastructure, quality of air transport infrastructure, available airline seat kilometers, quality of electricity supply, mobile telephone subscriptions, and fixed-telephone lines. (p. 322) 
3. Third pillar: Macroeconomic environment. Components: government budget balance, gross national savings, inflation, government debt, and country credit rating. (p. 322)

4. Fourth pillar: Health and primary education. Components: business impact of malaria, malaria incidence, business impact of tuberculosis, tuberculosis incidence, business impact of HIV/AIDS, HIV prevalence, infant mortality, life expectancy, quality of primary education, and primary education enrollment rate. (p. 322)

5. Fifth pillar: Higher education and training. Components: secondary education enrollment rate, tertiary education enrollment rate, quality of the educational system, quality of math and science education, quality of management schools, Internet access in schools, local availability of specialized research and training services, and extent of staff training. (p. 322)

6. Sixth pillar: Goods market efficiency. Components: intensity of local competition, extent of market dominance, effectiveness of anti-monopoly policy, effect of taxation on incentives to invest, total tax rate, number of procedures required to start a business, time required to start a business, agricultural policy costs, prevalence of trade barriers, trade tariffs, prevalence of foreign ownership, business impact of rules on FDI, burden of customs procedures, imports as a percentage of GDP, degree of customer orientation, and buyer sophistication. (p. 322)

7. Seventh pillar: Labor market efficiency. Components: cooperation in labor-employer relations, flexibility of wage determination, hiring and firing practices, redundancy costs, effect of taxation on incentives to work, pay and productivity, reliance on professional management, country capacity to retain talent, country capacity to attract talent, and female participation in labor force. (p. 322)

8. Eighth pillar: Financial market development. Components: financial services meeting business needs, affordability of financial services, financing through local equity market, ease of access to loans, venture capital availability, soundness of banks, regulation of securities exchanges, and legal rights index. (p. 323)

9. Ninth pillar: Technological readiness. Components: availability of latest technologies, firm-level technology absorption, FDI and technology transfer, Internet users, broadband Internet subscriptions, Internet bandwidth, mobile-broadband subscriptions, mobile telephone subscriptions, and fixed telephone lines. (p. 323)

10. Tenth pillar: Market size. Components: domestic market size index and foreign market size index. (p. 323)

11. Eleventh pillar: Business sophistication. Components: local supplier quantity, local supplier quality, state of cluster development, nature of competitive advantage, value chain breadth, control of international distribution, production process sophistication, extent of marketing, willingness to delegate authority, and reliance on professional management. (p. 323)

12. Twelfth pillar: Innovation. Components: capacity for innovation, quality of scientific research institutions, company spending on $\mathrm{R} \& \mathrm{D}$, university-industry collaboration in $\mathrm{R} \& \mathrm{D}$, government procurement of advanced technology products, availability of scientists and engineers, PCT patent applications, and intellectual property protection. (p. 323) 
Despotovic, Cvetanovic, Nedic, and Despotovic (2016) explained that: "Although value creation and productivity improvement remain the base of economic growth and competitiveness for certain countries, it is of essential importance to review the nature of the bonds between the economic, social, and environmental dimensions of sustainable competitiveness" (p. 1675) and that: "These three dimensions of the sustainable competitiveness phenomenon are clearly related to each other" (p. 1675). Despotovic et. al (2016) also indicated that: "Sustainable economic growth, which enables continual standard of living, depends on finding a balance between economic progress and the demands of social and environmental sustainability" (p. 1675). Then, the sustainable land management is critical for the sustainable competitiveness of the countries.

Although "over the last decade, promotion of competitiveness represents one of the central goals of economic policy of most of the countries" (Despotovic, Cvetanovic, Nedic, \& Despotovic, 2016, p. 1656), as can be appreciated, SLM is a critical pillar that has been forgotten in the Global Competitiveness Index. Another related index is the Doing Business Index, which measures "aspects of business regulation affecting domestic small and medium-size firms defined based on standardized case scenarios and located in the largest business city of each economy" (World Bank, 2018, p. 11). According to the World Bank (2018), the indicators measured in the Doing Business Index are as follows:

$\checkmark$ Starting a business: "Procedures, time, cost and paid-in minimum capital to start a limited liability company" (p. 12).

$\checkmark$ Dealing with construction permits: "Procedures, time and cost to complete all formalities to build a warehouse and the quality control and safety mechanisms in the construction permitting system" (p. 12).

$\checkmark$ Getting electricity: "Procedures, time and cost to get connected to the electrical grid, the reliability of the electricity supply and the transparency of tariffs" (p. 12).

$\checkmark$ Registering property: "Procedures, time and cost to transfer a property and the quality of the land administration system" (p. 12).

$\checkmark$ Getting credit: "Movable collateral laws and credit information systems" (p. 12).

$\checkmark$ Protecting minority investors: "Minority shareholders' rights in related-party transactions and in corporate governance" (p. 12).

$\checkmark$ Paying taxes: "Payments, time and total tax and contribution rate for a firm to comply with all tax regulations as well as post-filing processes" (p. 12).

$\checkmark$ Trading across borders: "Time and cost to export the product of comparative advantage and import auto parts" (p. 12).

$\checkmark$ Enforcing contracts: "Time and cost to resolve a commercial dispute and the quality of judicial processes" (p. 12).

$\checkmark$ Resolving insolvency: "Time, cost, outcome and recovery rate for a commercial insolvency and the strength of the legal framework for insolvency" (p. 12).

$\checkmark$ Labor market regulation: "Flexibility in employment regulation and aspects of job quality" (p. 12).

As can be appreciated, the environmental conservation or protection is not part of the indicators measured in the Doing Business Index. Additionally, apart from the Global Competitiveness Index and the Doing Business Index, there are some indexes which considered environmental issues, such as the Social Progress Index (Porter, Stern, \& Green, 2017) and the Environmental Performance Index (Yale University, 2018); however, these indexes are not considered to be associated with competitiveness directly. In the next section, the impact of the SLM on competitiveness is explained. 


\section{SLM: Definition and Its Impact on Competitiveness}

Critchley and Radstake (2017) explained that SLM has emerged over the last 20 years as "the most commonly acceptable current international term and concept, rather than soil conservation, soil and water conservation, land degradation control, or integrated ecosystem management-though each of these is still used in specific situations" (p. 8). Maisharou et al. (2015) commented that "SLM is also considered as a tool for harmonisation of interventions between the major sub-sectors with respect to land use" (p. 1). Critchley and Radstake (2017) further indicated that: "From an economic perspective, land degradation can adversely affect food security, which in turn affects population well-being, labor productivity, and, henceforth, economic growth and development as well as political stability" (p. 6).

The officials of GEF, UNEP, and FAO (2013) explained that: "The main objective of SLM is to promote long-lasting human coexistence with nature, in order that the provisioning, regulating, cultural and supporting services of ecosystems are assured for future generations" (p. vi) and that "SLM is an essential prerequisite for sustainable development" (p. vii). GEF is the Global Environment Facility. About the Global Environment Facility (GEF), Delreux (2018) indicated that it serves as: "the financial mechanism of the main climate, biodiversity, desertification, chemicals and ozone agreements" (p. 21). UNEP is the United Nations Environment Programme. FAO is the Food and Agriculture Organization of the United Nations.

The specialists of the WOCAT (2010) defined SLM as: "the use of land resources, including soils, water, animals and plants, for the production of goods to meet changing human needs, while simultaneously ensuring the long-term productive potential of these resources and the maintenance of their environmental functions" (p. i). WOCAT is the World Overview of Conservation Approaches and Technologies. The specialists of the World Bank (2008) also explained that SLM is a "knowledge-based procedure that helps integrate land, water, biodiversity, and environmental management (including input and output externalities) to meet rising food and fiber demands while sustaining ecosystem services and livelihoods" (p. 5). Critchley and Radstake (2017) also pointed out that "one of the most important elements of the "new approach" to conservation, underpinning the evolution of sustainable land management is the acknowledgement of indigenous knowledge and tradition" (p. 11) and that "farming has been practiced for over 10,000 years, yet for all but the last 200 years or so, the breeding of plants and animals, production systems, pest control, fertility maintenance, soil and water conservation, and irrigation have all been developed by land users themselves" (p. 11).

Despotovic et al. (2016) tested the hypothesis about "the positive impact of its social and environmental dimension on the economic dimension of sustainable competitiveness that is represented by the value of the Global Competitiveness Index" (p. 1656) with a sample of 34 European countries. The results of the study of Despotovic et al. (2016) confirmed the following:

the indisputable positive impact of the social dimension of sustainability, but also variable direction of the impact of the environmental dimension of sustainability (depending on the level of GDP per capita) on the economic dimension of sustainable competitiveness of European countries in 2013 (p. 1656).

In respect to the impact of biodiversity on climate change, Hisano, Searle, and Chen (2018) explained that "biodiversity may mitigate climate change impacts on (I) biodiversity itself, as more-diverse systems could be more resilient to climate change impacts, and (II) ecosystem functioning through the positive 
relationship between diversity and ecosystem functioning" (p. 439). Hisano et al. (2018) further explained that "forest ecosystems are critical to mitigating greenhouse gas emissions through carbon sequestration" (p. 439) and that "climate change has affected forest ecosystem functioning in both negative and positive ways, and has led to shifts in species/functional diversity and losses in plant species diversity which may impair the positive effects of diversity on ecosystem functioning" (p. 439).

D'Odorico, Bhattachan, Davis, Ravi, and Runyan (2013) defined desertification as the "change in soil properties, vegetation or climate, which results in a persistent loss of ecosystem services that are fundamental to sustaining life" (p. 326). About the impact of desertification, D'Odorico et al. (2013) explained that "desertification affects large dryland areas around the world and is a major cause of stress in human societies" (p. 326) and that "a multidisciplinary approach to understanding the drivers and feedbacks of global desertification is motivated by our increasing need to improve global food production and to sustainably manage ecosystems in the context of climate change" (p. 326). D'Odorico et al. (2013) also explained that "desertification feedbacks may involve land degradation processes (e.g., nutrient loss or salinization), changes in rainfall regime resulting from land-atmosphere interactions (e.g., precipitation recycling, dust emissions), or changes in plant community composition (e.g., shrub encroachment, decrease in vegetation cover)" (p. 326). The authors further pointed out that "desertification typically results from the compound effect of climate change and land use" (p. 332) and that "the long-range effects of desertification modify climate, global biogeochemical cycles and human geography” (p. 335).

About global climate change, Masih (2010) explained that it indicates "a change in either the mean state of the climate or in its variability, persisting for several decades or longer" (p. 102). In respect to the consequences of climate change, Masih (2010, p. 107) indicated the following effects of climate change: (a) the sea level is rising, (b) the arctic sea ice is melting, (c) glaciers and permafrost are melting, (d) seasurface temperatures are warming, (e) heavier rainfall causes flooding in many regions, (f) extreme drought is increasing, (g) hurricanes have changed in frequency and strength, (h) more frequent heat waves, (i) the warmer temperatures affect human health, and (j) seawater is becoming more acidic. Finally, these consequences have been affecting diverse economic sectors, such as: agriculture, health, infrastructure, financial markets, tourism, and so on, with the consequent reduction of the competitiveness of those sectors in various countries.

\section{Some Partial Frameworks about SLM}

This section details previous studies and management instruments at the international and national levels for SLM. These studies and management instruments have been taken as a reference to propose an integrated management framework for interventions of SLM at the national, regional, and local levels, and that permits to take full advantage of the synergies between the related actors, stakeholders, and resources.

\section{Environmental monitoring for the SLM in productive landscapes from New Zealand}

MacLeod and Moller (2013, p. vi) proposed a framework for an environmental monitoring program in New Zealand, in which four outcomes were specified, along with their objectives and indicators, as follows: 
1. Outcome E1: Natural Capital Maintained. Objectives:

A. Maintaining ecosystem processes. Indicators: (a) soil status, (b) water quality and yield, (c) land cover, (d) ecosystem disruption, and (e) pollination.

B. Reducing agricultural pest threats. Indicators: (a) new agricultural disease, weed, and pest species and (b) agricultural disease, weed, and pest dominance.

C. Limiting environmental pollutants. Indicators: (a) environmental risk of toxins and (b) ecosystem levels of persistent toxins.

\section{Outcome E2: Resilience Secured for Future Use. Objectives:}

A. Minimizing material and energy subsidies. Indicators: (a) non-renewable materials and (b) energy use.

B. Buffering against socio-economic pressures and shocks. Indicators: (a) agro-environmental financial resources and (b) agro-environmental governance.

C. Maintaining agro-biodiversity. Indicators: (a) genetic stock, (b) beneficial species status, and (c) landscape functional heterogeneity.

\section{Outcome E3: Contributed to National 'Natural Heritage' Goals. Objectives:}

A. Improving ecosystem representation and composition. Indicators: (a) ecosystem representation and protection, (b) ecosystem composition, and (c) occupancy of environmental range.

B. Preventing extinctions and declines. Indicator: status of threatened species.

C. Reducing conservation pest threats. Indicator: (a) new conservation weed and pest species, and (b) conservation weed and pest dominance.

\section{Outcome E4: Global Environmental Change Obligations Met. Objectives:}

A. Reducing emissions. Indicator: greenhouse gas emissions.

B. Increasing carbon sequestration. Indicator: carbon storage and fluxes.

\section{Causes and consequences of land use change in Santiago, Chile}

Matta (2008) proposed a framework with the direct and indirect causes, as well as the consequences of the land use change (p. 5). The indirect causes were as follows: demographic factors, economic factors, technological factors, governmental policies, and cultural factors; also, the indirect causes influence infrastructure development, agriculture expansion, and wood extraction. Matta (2008, p. 5) also indicated the following direct causes: (a) social trigger events (which influence land ownership); (b) infrastructure development, agriculture expansion, and wood extraction (which influence land management); and (c) climate change (which influences land characteristics). With respect to the land use change and the land system (comprising land ownership, land management, and land characteristics), Matta (2008) specified the following direct consequences:

1. Related to land ownership: (a) land tenancy conflicts, (b) expropriation conflicts, (c) resettlement of native communities, and (d) loss of cultural / religious areas.

2. Related to land management: (a) nonproductive land uses, (b) urban sprawl, (c) overgrazing, and (d) rural population decline. 
3. Related to land characteristics: (a) soil and rangeland pollution and degradation, (b) deforestation and native forest loss, (c) soil quality decrease, and (d) soil erosion.

Matta (2008) also specified the indirect consequences associated with the land use change: (a) social discontent, (b) abandonment of marginal lands, (c) institutional problems, (d) water availability and water quality diminishment, (e) ecosystems fragmentation, (f) changes in microclimates, (g) rise of social organizations, (h) loss of agricultural land, (i) urban population increase, (j) NIMBY ("Not In My Back Yard") effect, (k) political dichotomy, (l) politic and institutional credibility and confidence fall, (m) loss of biodiversity, (n) diminishment of food production, (o) floods and droughts, (p) project overlapping and waste of time, among others.

\section{Guidelines for the National Assessment of Land Degradation and SLM of the LADA Project}

The specialists of GEF, UNEP, and FAO (2013) proposed guidelines for the national assessment of land degradation and SLM through the LADA Project (Land Degradation Assessment in Drylands). The specialists of GEF, UNEP, and FAO (2013) also indicated that the purposes of the evaluation are the following: (a) to obtain a reliable image of the state of natural resources and their use in the country; (b) to prepare the way to establish a monitoring system for land use, land degradation, and land management; (c) to prepare the way and identify areas of greatest interest for more local and detailed evaluations; (d) to provide information (results) to inform decision makers about the wisest uses of natural resources, particularly land and water; and (e) to provide a reliable basis for reporting to different conventions in particular to the UNCCD, UNFCCC, and UNCBD. Additionally, the specialists of GEF, UNEP, and FAO (2013) detailed the phases of the evaluation, as follows:

\section{Preparatory phase}

A national workshop should be organized to explain the objectives of carrying out the inventory and the baseline involving multiple disciplines (agriculture, livestock, forests, statistics, natural resources, and environment). The workshop should give an overview of the state-of-the-art of the current inventory available within ministries and institutions of data on land resources (soil, climate, land cover, and topography), land use (hat is the crop, levels of inputs, levels of management? or What is the extent and intensity of irrigation?), and specific information on the particular good practices applied to agriculture, pasture, and forest management. The availability of information should also be discussed on economic or social factors, particularly in the population and poverty sub-nationally. It is important to note that this first workshop must set the bases to involve the national scientific and technical community in the evaluation exercise, to obtain a widely accepted product and create the conditions to establish better collaboration between the involved institutions. The result of this first national workshop should be an agreement on:

a. The leading institution that will coordinate the work.

b. Institutions and ministries that will cooperate by collecting or elaborating available data and personnel to carry out the baseline study.

c. Financial arrangements.

\section{Phase 1: Preparation of a concerted national map about land use}

a. The preparation of the base materials. The base materials include: (i) national maps of soils, climate, vegetation cover, and land uses (irrigated and protected); (ii) national and sub-national statistics of socio- 
economic factors about the density of the population, poverty levels, use of inputs (tractors and fertilizers), average yields of specific crops, land tenure arrangements, density classes of livestock and dominant livestock species; and (iii) regional and global data with sufficient graphic resolution for being used in national studies.

b. The preparation of the base map. The base map is the map of the National System of Land Use. This map should be prepared and documented by the lead institution in collaboration with your team in other national ministries and institutions.

c. The map of the national system of land use: delineating units. The starting point for the preparation of the map of the national system of land use is the information land cover, freely available for 2005 for everyone with a graphic resolution in a scale of $300 \mathrm{~m}$. The use of the Globcover database is highly recommended to avoid significant errors.

d. The map of the national system of land use: attributes of the delineated units. Cross georeferenced information of the national system of land use with socio-economic information.

e. Validation of the national map of land use. This validation must be carried out through a workshop, involving the same institutions and ministries that participated in the first workshop, with the additional presence of representatives of farmers' organizations or forest rangers and extension agents of each large administrative unit in the country. In this meeting, the map must be submitted to the validation of experts with experience in the land and the changes must be made where required. It is very important that the principles on which the map is built are accepted by all the participants.

The final result of this phase has three parts:

a. A central digital information system that contains maps, data, and information on the natural resources in the country, accessible by all actors.

b. A unique national map of the land use system that can be used as a basis for the assessment and mapping of land degradation and sustainable management.

c. The evaluation team has agreed and supported the map.

\section{Phase 2: Assessment of land degradation and SLM}

The questionnaire and software for land degradation and SLM are available on the LADA website. The activities of this phase are the following:

a. Organization of the evaluation. The participation of teams of actors at the national and sub-national levels, including land users, extension agents, and district officials should be organized.

b. Preparation of the evaluation team. Before starting the evaluation, the questionnaire should be shared with a number of experts to facilitate the process in the areas that will be investigated. Then, a short workshop should be organized by the lead institution to introduce experts from different areas in the use of the WOCAT / LADA questionnaire.

c. The participatory evaluation. Administrative units should collaborate with measurable data for the lead institution and the lead institution must ensure that all maps and background information gathered to prepare the national map of land use are available. Google Earth maps, images and maps printed on a larger scale can often be very helpful. Depending on the dominant land uses, specialists in crops, livestock, and forestry should be associated with the evaluation, as well as the evaluation of sociologists and economists.

d. Quality control. The questionnaire has verification entries that must be reviewed by administrative units. There are more sophisticated controls that were developed by the Free University of Amsterdam in 
collaboration with LADA Senegal and that are available under the shape of a working paper on the LADA website.

\section{Phase 3: Consolidation into a simple national product with related results, maps, and analysis}

a. Mapping of individual degradation and management characteristics.

b. Combined mapping of the types of land degradation.

c. National mapping of SLM.

d. Analysis and interpretation of the mapping and questionnaires.

\section{Phase 4: Feedback to users}

A final workshop should be organized with the stakeholders involved in the first workshop, to discuss the results and evaluate the implications for land use and environmental planning. The authorities and the actors in the administrative units must also be involved in this final workshop. Agreements must be reached to order the results for the report. The exercise should be repeated within 5 to 10 years to monitor the results.

It is important to observe that the specialists of PBL Netherlands Environmental Assessment Agency (2014) described GlobCover database as follows: "Global composites and land cover maps using as input observations from the 300m MERIS sensor on board the ENVISAT satellite mission."

\section{Mapping global archetypes of land systems}

Václavík, Lautenbach, Kuemmerle, and Seppelt (2013, p. 3) proposed the following global archetypes of land systems:

1. Land-use intensity factors: (a) area of farmland, (b) trend in the area of farmland, (c) pasture area, (d) tendency in the pasture area, (e) number of fertilizers, (f) irrigation, (g) soil erosion, (h) yields of crops (wheat, corn, and rice), (i) gaps of yields of crops (wheat, corn, and rice), (i) total production index, and (k) Human Appropriation of Net Primary Production (HANPP).

2. Environmental factors: (a) temperature, (b) daytime temperature range, (c) precipitation, (d) temporality of precipitation, (e) solar radiation, (f) climatic anomalies, (g) average NDVI (Normalized Difference Vegetation Index), (h) temporality of NDVI, (i) organic carbon of soil, and (j) wealth of species.

3. Socio-economic factors: (a) gross domestic product, (b) gross domestic product in agriculture, (c) social capital in agriculture, (d) population density, (e) trend in population density, (f) political stability, and $(\mathrm{g})$ accessibility.

\section{Sustainable Forestry Initiative}

Sustainable Forestry Initiative (2010) proposed the SFI 2010-2014 Standard, whose principles, objectives, and performance measures were the following: 
1. Principles: (a) sustainable forestry, (b) forest health and productivity, (c) protection of water resources, (d) protection of biological diversity, (e) aesthetics and recreation, (f) protection of special sites, (g) responsible practices for fiber supply in North America, (h) legal compliance, (i) investigation, (j) training and education, (k) public involvement, (l) transparency, and (m) continual improvement (p. 3).

\section{Objectives and performance measures:}

A. Objective 1: Forest Management Planning. Performance measure 1.1: "Program Participants shall ensure that forest management plans include long-term harvest levels that are sustainable and consistent with appropriate growth-and-yield models" (p. 5).

B. Objective 2: Forest Productivity. Performance measures:

a. Performance measure 2.1: "Program Participants shall promptly reforest after final harvest" (p. 5).

b. Performance measure 2.2: "Program Participants shall minimize chemical use required to achieve management objectives while protecting employees, neighbors, the public and the environment, including wildlife and aquatic habitats" (p. 6).

c. Performance measure 2.3: "Program Participants shall implement forest management practices to protect and maintain forest and soil productivity" (p. 6).

d. Performance measure 2.4: "Program Participants shall manage to protect forests from damaging agents, such as environmentally or economically undesirable wildfire, pests, diseases and invasive exotic plants and animals, to maintain and improve long-term forest health, productivity, and economic viability" (p. 6).

e. Performance measure 2.5: "Program Participants that deploy improved planting stock, including varietal seedlings, shall use sound scientific methods" (p. 7).

C. Objective 3: Protection and Maintenance of Water Resources. Performance measures:

a. Performance measure 3.1: "Program Participants shall meet or exceed all applicable federal, provincial, state and local water quality laws, and meet or exceed best management practices developed under Canadian or U.S. Environmental Protection Agency-approved water quality programs" (p. 7).

b. Performance measure 3.2: "Program Participants shall have or develop, implement and document riparian protection measures based on soil type, terrain, vegetation, ecological function, harvesting system and other applicable factors" (p. 7).

D. Objective 4: Conservation of Biological Diversity including Forests with Exceptional Conservation Value. Performance measures:

a. Performance measure 4.1: "Program Participants shall have programs to promote biological diversity at stand- and landscape-levels" (p. 7).

b. Performance measure 4.2: "Program Participants shall apply knowledge gained through research, science, technology and field experience to manage wildlife habitat and contribute to the conservation of biological diversity" (p. 8).

E. Objective 5: Management of Visual Quality and Recreational Benefits. Performance measures:

a. Performance measure 5.1: "Program Participants shall manage the impact of harvesting on visual quality" (p. 7). 
b. Performance measure 5.2: "Program Participants shall manage the size, shape and placement of clearcut harvests" (p. 8).

c. Performance measure 5.3: "Program Participants shall adopt a green-up requirement or alternative methods that provide for visual quality" (p. 8).

d. Performance measure 5.4: "Program Participants shall support and promote recreational opportunities for the public" (p. 8).

F. Objective 6: Protection of Special Sites. Performance measure 6.1: "Program Participants shall identify special sites and manage them in a manner appropriate for their unique features" (p. 8).

G. Objective 7: Efficient Use of Forest Resources. Performance measure 7.1: "Program Participants shall employ appropriate forest harvesting technology and in-woods manufacturing processes and practices to minimize waste and ensure efficient utilization of harvested trees, where consistent with other SFI Standard objectives" (p. 9).

H. Objective 8: Landowner Outreach. Performance measure 8.1: "Program Participants shall provide information to landowners for reforestation following harvest, for the use of best management practices, and for identification and protection of important habitat elements for wildlife and biodiversity, including Forests with Exceptional Conservation Value" (p. 9).

I. Objective 9: Use of Qualified Resource and Qualified Logging Professionals. Performance measure 9.1: "Program Participants shall encourage landowners to utilize the services of certified logging professionals (where available), qualified resource professionals and qualified logging professionals in applying principles of sustainable forest management on their lands" (p. 9).

J. Objective 10: Adherence to Best Management Practices. Performance measurements:

a. Performance measure 10.1: "Program Participants shall clearly define and implement policies to ensure that facility inventories and fiber sourcing activities do not compromise adherence to the principles of sustainable forestry" (p. 9).

b. Performance measure 10.2: "Program Participants shall monitor the use of best management practices" (p. 10).

K. Objective 11: Promote Conservation of Biological Diversity, Biodiversity Hotspots, and HighBiodiversity Wilderness Areas. Performance measure 11.1: "Program Participants shall ensure that their fiber sourcing programs support the principles of sustainable forestry, including efforts to promote conservation of biological diversity" (p. 10).

L. Objective 12: Avoidance of Controversial Sources including Illegal Logging. Performance measure 12.1: "Program Participants shall ensure that their fiber sourcing programs support the principles of sustainable forestry, including efforts to thwart illegal logging" (p. 10).

M. Objective 13: Avoidance of Controversial Sources including Fiber Sourced from Areas without Effective Social Laws. Performance measure 13.1: "Program Participants shall avoid controversial sources and encourage socially sound practices" (p. 10). 


\section{N. Objective 14: Legal and Regulatory Compliance. Performance measures:}

a. Performance measure 14.1: "Program Participants shall take appropriate steps to comply with applicable federal, provincial, state, and local forestry and related social and environmental laws and regulations" (p. 11).

b. Performance measure 14.2: "Program Participants shall take appropriate steps to comply with all applicable social laws at the federal, provincial, state and local levels in the country in which the Program Participant operates" (p. 11).

\section{O. Objective 15: Forestry Research, Science, and Technology. Performance measures:}

a. Performance measure 15.1: "Program Participants shall individually and/or through cooperative efforts involving SFI Implementation Committees, associations or other partners provide in-kind support or funding for forest research to improve forest health, productivity, and sustainable management of forest resources, and the environmental benefits and performance of forest products" (p. 11).

b. Performance measure 15.2: "Program Participants shall individually and/or through cooperative efforts involving SFI Implementation Committees, associations or other partners develop or use state, provincial or regional analyses in support of their sustainable forestry programs" (p. 11).

\section{P. Objective 16: Training and Education. Performance measures:}

a. Performance measure 16.1: "Program Participants shall require appropriate training of personnel and contractors so that they are competent to fulfill their responsibilities under the SFI 2010-2014 Standard" (p. 12).

b. Performance measure 16.2: "Program Participants shall work individually and/or with SFI Implementation Committees, logging or forestry associations, or appropriate agencies or others in the forestry community to foster improvement in the professionalism of wood producers" (p. 12).

\section{Q. Objective 17: Community Involvement in the Practice of Sustainable Forestry. Performance measures:}

a. Performance measure 17.1: Program Participants shall support and promote efforts by consulting foresters, state, provincial, and federal agencies, state or local groups, professional societies, conservation organizations, indigenous peoples and governments, community groups, sporting organizations, labor, universities, extension agencies, the American Tree Farm System ${ }^{\circledR}$ and/or other landowner cooperative programs to apply principles of sustainable forest management (p. 13).

b. Performance measure 17.2: "Program Participants shall support and promote, at the state, provincial, or other appropriate levels, mechanisms for public outreach, education and involvement related to sustainable forest management" (p. 13).

c. Performance measure 17.3: "Program Participants shall establish, at the state, provincial, or other appropriate levels, procedures to address concerns raised by loggers, consulting foresters, employees, unions, the public, or other Program Participants regarding practices that appear inconsistent with the SFI Standard principles and objectives" (p. 13).

\section{R. Objective 18: Public Land Management Responsibilities. Performance measures:}

a. Performance measure 18.1: "Program Participants with forest management responsibilities on public lands shall participate in the development of public land planning and management processes" (p. 14). 
b. Performance measure 18.2: "Program Participants with forest management responsibilities on public lands shall confer with affected indigenous peoples" (p. 14).

\section{S. Objective 19: Communications and Public Reporting. Performance measures:}

a. Performance measure 19.1: "A Certified Program Participant shall provide a summary audit report, prepared by the certification body, to SFI Inc. after the successful completion of a certification, recertification, or surveillance audit to the SFI 2010-2014 Standard" (p. 14).

b. Performance measure 19.2: "Program Participants shall report annually to SFI Inc. on their conformance with the SFI 2010-2014 Standard" (p. 14).

T. Objective 20: Management Review and Continual Improvement. Performance measure 20.1: "Program Participants shall establish a management review system to examine findings and progress in implementing the SFI Standard, to make appropriate improvements in programs, and to inform their employees of changes" (p. 14).

\section{SALUS Model (System Approach for Land Use Sustainability)}

Basso and Ritchie (2015, p. 261) explained the components of the model SALUS (System Approach for Land Use Sustainability), which were the following: (a) biotic interactions, (b) crops (wheat, barley, maize, soy, potato, etc.), (c) roots, (d) weather, (e) soil, and (f) management (crop sequencing, planting, residue, tillage, fertilizers, manure, pesticides, irrigation, and drainage). Basso and Ritchie (2015) also indicated that these components affect the yield, the atmospheric flux, drainage leaching, and soil erosion, and that the previous issues affect socio-economic and environmental factors (p. 261).

\section{SLM Project in The Gambia}

Chileshe, Oladapo, Shalaby, Telahigue, and Sarr (2010, p. 4) explained the components of the SLM project in the Gambia, as well as the main used management indicators, which are the following:

\section{Components of the project:}

A. Institutional strengthening of SLM. It includes: (a) establishment and operation of the national platform for sustainable land management in The Gambia, (b) establishment and operation of six regional platforms for sustainable land management, (c) formulation of the framework for investments in sustainable land management, (d) development of a knowledge base and an information system for sustainable land management, (e) assistance in the development of appropriate policies in agricultural mechanization, and (f) construction of key planning capacity and advice to support service providers.

B. Landscape and basin management based on community participation: (a) watershed management planning based on community participation, (b) assurance of food safety, routing poverty, and land degradation towards a community based in sustainable land management investment with community participation, (c) monitoring and evaluation of the impact in a participatory manner, (d) construction of the institutional capacity for the planning of watershed management based on the participation of the community, and (e) validation and demonstration of agricultural conservation tools and techniques for mountain agriculture. 
C. Project management: (a) to develop and execute annual supply plans, (b) to implement an internal system for the management of monitoring / evaluation, (c) to prepare and submit quarterly reports, to review the medium term and to report the progress of the project, and (d) to monitor agreements with implementing partners.

2. Indicators of environmental management. In the project of sustainable land management, among others, the following environmental indicators were specified: (a) use of land (arable land as a percentage of the total land area), (b) annual rate of deforestation, (c) annual reforestation rate, and (d) $\mathrm{CO}_{2}$ emissions per capita (metric tons).

\section{The 10-year strategic plan and framework to enhance the implementation of the UNCCD (2008-2018)}

The participants of the COP 8 of the UNCCD celebrated in Madrid at September 2007 proposed the four strategic objectives and the five operational objectives (United Nations, 2007, p. 16). The four strategic objectives are the following:

1. Strategic objective 1: To improve the living conditions of affected populations.

Expected impact 1.1: People living in areas affected by desertification/land degradation and drought to have an improved and more diversified livelihood base and to benefit from income generated from sustainable land management.

Expected impact 1.2: The affected populations' socio-economic and environmental vulnerability to climate change, climate variability, and drought is reduced.

Indicator S-1: Decrease in numbers of people negatively impacted by the processes of desertification/land degradation and drought.

Indicator S-2: Increase in the proportion of households living above the poverty line in affected areas.

Indicator S-3: Reduction in the proportion of the population below the minimum level of dietary energy consumption in affected areas.

2. Strategic objective 2: To improve the conditions of affected ecosystems.

Expected impact 2.1. Land productivity and other ecosystem goods and services in affected areas are enhanced in a sustainable manner contributing to improved livelihoods.

Expected impact 2.2. The vulnerability of affected ecosystems to climate change, climate variability, and drought is reduced.

Indicator S-4: Reduction in the total area affected by desertification/land degradation and drought.

Indicator S-5: Increase in the net primary productivity in affected areas. 
3. Strategic objective 3: To generate global benefits through the effective application of the UNCCD.

Expected impact 3.1. Sustainable land management and combating desertification/land degradation contribute to the conservation and sustainable use of biodiversity and the mitigation of climate change.

Indicator S-6: Increase in carbon stocks (soil and plant biomass) in affected areas.

Indicator S-7: Areas of forest, agricultural, and aquaculture ecosystems under sustainable management.

4. Strategic objective 4: To mobilize resources to support implementation of the Convention through building effective partnerships between national and international actors.

Expected impact 4.1. Increased financial, technical, and technological resources are made available to affected developing country Parties, and where appropriate Central and Eastern European countries, to implement the Convention.

Expected impact 4.2. Enabling policy environments are improved for UNCCD implementation at all levels.

Indicator S-8: Increase in the level and diversity of available funding for combating desertification/land degradation and mitigating the effects of drought.

Indicator S-9: Development policies and measures address desertification/land degradation and mitigation of the effects of drought.

The five operational objectives of the Decennial Strategic Plan 2008-2018 (United Nations, 2007, p. 18) are as follows:

1. Operational objective 1: Advocacy, awareness raising, and education.

To actively influence relevant international, national, and local processes and actors in adequately addressing desertification/land degradation and drought-related issues.

Outcome 1.1: Desertification/land degradation and drought issues and the synergies with climate change adaptation/mitigation and biodiversity conservation are effectively communicated among key constituencies at the international, national, and local levels.

Outcome 1.2: Desertification/land degradation and drought issues are addressed in relevant international forums, including those pertaining to agricultural trade, climate change adaptation, biodiversity conservation and sustainable use, rural development, sustainable development, and poverty reduction.

Outcome 1.3: Civil society organizations (CSOs) and the scientific community in the North and the South are increasingly engaged as stakeholders in the Convention processes and desertification/land degradation and drought are addressed in their advocacy, awareness-raising, and education initiatives.

2. Operational objective 2: Policy framework.

To support the creation of enabling environments for promoting solutions to combat desertification/land degradation and mitigate the effects of drought. 
Outcome 2.1: Policy, institutional, financial, and socio-economic drivers of desertification/land degradation and barriers to sustainable land management are assessed, and appropriate measures to remove these barriers are recommended.

Outcome 2.2: Affected country parties revise their national action programmes (NAPs) into strategic documents supported by biophysical and socio-economic baseline information and include them in integrated investment frameworks.

Outcome 2.3: Affected country parties integrate their NAPs and sustainable land management and land degradation issues into development planning and relevant sectorial and investment plans and policies.

Outcome 2.4: Developed country parties mainstream UNCCD objectives and sustainable land management interventions into their development cooperation programmes/projects in line with their support to national sectorial and investment plans.

Outcome 2.5: Mutually reinforcing measures among desertification/land degradation action programmes and biodiversity and climate change mitigation and adaptation are introduced or strengthened so as to enhance the impact of interventions.

3. Operational objective 3: Science, technology, and knowledge.

To become a global authority on scientific and technical knowledge pertaining to desertification/land degradation and mitigation of the effects of drought.

Outcome 3.1: National monitoring and vulnerability assessment on biophysical and socioeconomic trends in affected countries are supported.

Outcome 3.2: A baseline based on the most robust data available on biophysical and socioeconomic trends is developed and relevant scientific approaches are gradually harmonized.

Outcome 3.3: Knowledge on biophysical and socio-economic factors and on their interactions in affected areas is improved to enable better decision-making.

Outcome 3.4: Knowledge of the interactions between climate change adaptation, drought mitigation and restoration of degraded land in affected areas is improved to develop tools to assist decision-making.

Outcome 3.5: Effective knowledge-sharing systems, including traditional knowledge, are in place at the global, regional, subregional, and national levels to support policymakers and end users, including through the identification and sharing of best practices and success stories.

Outcome 3.6: Science and technology networks and institutions relevant to desertification/land degradation and drought are engaged to support UNCCD implementation.

\section{Operational objective 4: Capacity-building.}

To identify and address capacity-building needs to prevent and reverse desertification/land degradation and mitigate the effects of drought. 
Outcome 4.1: Countries which have carried out the national capacity self-assessment (NCSA) implement the resulting action plans to develop the necessary capacity at the individual, institutional, and systemic levels to tackle desertification/land degradation and drought issues at the national and local levels.

Outcome 4.2: Those countries which have not previously undertaken capacity needs assessments engage in relevant assessments processes to identify capacity needs for tackling desertification/land degradation and drought at the national and local levels

\section{Operational objective 5: Financing and technology transfer.}

To mobilize and improve the targeting and coordination of national, bilateral and multilateral financial and technological resources in order to increase their impact and effectiveness.

Outcome 5.1: Affected country parties develop integrated investment frameworks for leveraging national, bilateral, and multilateral resources with a view to increasing the effectiveness and impact of interventions.

Outcome 5.2: Developed country parties provide substantial, adequate, timely, and predictable financial resources to support domestic initiatives to reverse and prevent desertification/land degradation and mitigate the effects of drought.

Outcome 5.3: Parties increase their efforts to mobilize financial resources from international financial institutions, facilities and funds, including the GEF, by promoting the UNCCD/Sustainable land management (SLM) agenda within the governing bodies of these institutions.

Outcome 5.4: Innovative sources of finance and financing mechanisms are identified to combat desertification/land degradation and mitigate the effects of drought, including from the private sector, market-based mechanisms, trade, foundations and CSOs, and other financing mechanisms for climate change adaptation and mitigation, biodiversity conservation, and sustainable use and for hunger and poverty reduction.

Outcome 5.5: Access to technology by affected country parties is facilitated through adequate financing, effective economic and policy incentives and technical support, notably within the framework of SouthSouth and North-South cooperation.

\section{Agreements and indicators on Land Degradation Neutrality}

The officials of the United Nations (2016) endorsed the science-based definition of the Intergovernmental Working Group (IWG) for the Land Degradation Neutrality (LDN) as follows: "Land degradation neutrality is a state whereby the amount and quality of land resources necessary to support ecosystem functions and services and enhance food security remain stable or increase within specified temporal and spatial scales and ecosystems" (p. 9). The officials of the United Nations (2017) mentioned the objectives of the LDN as follows (p. 1):

$\checkmark$ maintain or improve the sustainable delivery of ecosystem services;

$\checkmark$ maintain or improve productivity, in order to enhance food security;

$\checkmark$ increase resilience of the land and populations dependent on the land; 
$\checkmark$ seek synergies with other social, economic, and environmental objectives; and

$\checkmark$ reinforce responsible and inclusive governance of land.

According to the officials of the United Nations (2016, p. 9), at the Twelfth Conference of the Parties (COP 12) of the UNCCD held on 21st October 2015, in relation to the integration of the Sustainable Development Goals (SDG) and its goals in the implementation of the UNCCD in the National Action Programs (NAP) and the report of the IWG on the Land Degradation Neutrality (LDN) for fighting the Desertification, Land Degradation and Drought (DLDD), it was agreed that parties are invited to:

(a) Formulate voluntary targets to achieve LDN in accordance with their specific national circumstances and development priorities, taking into account the list of options for operationalizing LDN at the national level as outlined by the IWG.

(b) Use the monitoring and evaluation approach adopted in decision 22/COP.11, including the progress indicators as listed in the annex to this decision, where reliable data is available pursuant to paragraph 7 of that decision and taking into consideration national circumstances and, as needed, add additional indicators to monitor, evaluate, and communicate progress towards achieving the LDN target.

(c) Explore options on how to integrate the voluntary LDN targets in their NAPs as part of their overall discussion on the implementation of the SDGs.

(d) Promote the use of LDN targets and projects and other SLM initiatives as an effective vehicle for mobilizing additional sustainable financing and responsible and sustainable investments that address DLDD issues.

The officials of the United Nations (2016, p. 11) proposed progress indicators for the strategic objectives of LDN, as follows:

$\checkmark$ Trends in population living below the relative poverty line and/or income inequality in affected areas;

$\checkmark$ Trends in access to safe drinking water in affected areas;

$\checkmark$ Trends in land cover;

$\checkmark$ Trends in land productivity or functioning of the land;

$\checkmark$ Trends in carbon stocks above and below ground;

$\checkmark$ Trends in abundance and distribution of selected species.

Purposes, Goals, and Indicators of National Strategies for Natural Resources in Peru

\section{Objectives and indicators of the National Strategy to Combat Desertification and Drought 2016-2030}

The specialists of the Ministry of Environment of Peru - MINAM (2016) proposed a general objective and six specific objectives in the National Strategy to Combat Desertification and Drought 2016-2030 (ENLCDS 2016-2030), with its corresponding management indicators:

1. General Objective: To prevent and reduce desertification, land degradation and the impact of drought in the national territory. The management indicators of the general objective are the following: 
$\checkmark$ IOG-1 Percentage of areas which were recovered from desertification, land degradation, and the impact of drought.

$\checkmark$ IOG-2 Percentage of areas in which actions have been implemented to prevent desertification, land degradation, and the impact of drought.

$\checkmark$ IOG-3 Increase in carbon stocks (soil and plant biomass) in the affected areas.

$\checkmark \quad$ IOG-4 Increase in net primary productivity of soils in affected areas.

$\checkmark$ IOG-5 Reduction in the number of people affected by desertification, land degradation, and drought, as a result of interventions.

$\checkmark$ IOG-6 Increase in the proportion of households living above the poverty line in the affected areas, as a result of the interventions carried out.

$\checkmark$ IOG-7 Reduction in the proportion of the population that is below the minimum level of food energy consumption in the affected areas, as a result of the interventions carried out.

\section{Specific Objectives:}

A. Specific Objective $\mathrm{N}^{\circ}$ 1: To elaborate and update the baselines of the state of soils, including the causes and consequences of desertification, land degradation and drought, with solid scientifictechnological guidelines adapted to the national reality. The management indicator for the Specific Objective $\mathrm{N}^{\circ} 1$ is:

$\checkmark$ IOE1: Percentage of regions that have developed and/or updated the baselines of the areas which were affected by desertification, land degradation, and drought.

B. Specific Objective $\mathrm{N}^{\circ} 2$ : Strengthen regulatory frameworks related to the fight against desertification, land degradation, and drought (synergistic, multi-sectorial, intra-sectorial, regional, and local), the affected areas, and the areas that could potentially be affected by the desertification, land degradation, and drought. The management indicator for the Specific Objective $N^{\circ} 2$ is:

$\checkmark$ IOE2: Percentage of entities related to the reduction of desertification, land degradation, and the impact of drought, which have sufficient regulatory frameworks for their effective participation.

C. Specific Objective $\mathrm{N}^{\circ}$ 3: To develop plans, programs, and projects that are synergistic, multi-sectorial, intra-sectorial, regional and local, to reduce the desertification, the land degradation, and the impact of drought in the affected areas and the areas that would potentially be affected. The management indicators of the Specific Objective $N^{\circ} 3$ are as follows:

$\checkmark$ IOE3-1: Percentage of related entities that have plans, programs, and projects that are synergistic, multi-sectorial, intra-sectorial, regional, and local to reduce desertification, land degradation, and the impact of drought.

$\checkmark$ IOE3-2: Percentage of progress in the execution of plans, programs, and projects that are synergistic, multi-sectorial, intra-sectorial, regional, and local to reduce desertification, land degradation, and the impact of drought.

$\checkmark$ IOE3-3: Percentage of budget execution of plans, programs, and projects to combat desertification, land degradation, and the impact of drought. 
D. Specific Objective $\mathrm{N}^{\circ}$ 4: To disseminate the problems and actions to mitigate desertification, land degradation, and the impact of drought through mass communication media. The management indicators of the Specific Objective $\mathrm{N}^{\circ} 4$ are as follows:

$\checkmark$ IOE4-1: Percentage of mass media that disseminate the problems and actions to reduce desertification, land degradation, and the impact of drought, periodically.

$\checkmark$ IOE4-2: Percentage of the population that knows the problems and actions to reduce desertification, land degradation, and the impact of drought.

E. Specific Objective $N^{\circ}$ 5: Strengthen management capacities of the theme of desertification, land degradation and drought, in the diverse stakeholders, on a scientific-technological basis adapted to the national reality. The management indicators of the Specific Objective $\mathrm{N}^{\circ} 5$ are as follows:

$\checkmark$ IOE5-1: Percentage of government entities related to the reduction of desertification, land degradation, and the impact of drought, which have received training for their effective participation.

$\checkmark$ IOE5-2: Percentage of non-governmental entities related to the reduction of desertification, land degradation, and the impact of drought, which have received training for their effective participation.

$\checkmark$ IOE5-3: Percentage of people associated with the theme of desertification, land degradation and drought, who have received training on this subject.

F. Specific Objective $\mathrm{N}^{\circ}$ 6: To develop scientific research or technological innovations that help sustainable land management, taking advantage of traditional national knowledge. The management indicators of the Specific Objective $\mathrm{N}^{\circ} 6$ are the following:

$\checkmark$ IOE6-1: Percentage of progress in the development of scientific research and technological innovations associated with sustainable land management.

$\checkmark$ IOE6-2: Percentage of progress in achieving the goal of publications in indexed journals associated with sustainable land management.

\section{Objectives and indicators of the National Strategy on Climate Change 2015}

In its National Strategy on Climate Change 2015 (wherein CC is Climate Change and GHG is GreenHouse Gases), the specialists of the MINAM (2015) proposed the following objectives and management indicators:

1. Objective 1: The population, economic agents, and the State increase awareness and adaptive capacity for action in the face of the adverse effects and opportunities of the $\mathrm{CC}$. The management indicators are the following:

a. Increase of the proportion of people who know what actions to take for risk management in a $\mathrm{CC}$ context and for adaptation to $\mathrm{CC}$;

b. Increase of private investment and increase of the quality of public spending for adaptation to $\mathrm{CC}$;

c. Reduction of losses of human and economic lives due to the occurrence of disasters of climatic origin; 
d. Increase in the production of scientific research and technological development as a basis and guide for risk management in a context of climate change and adaptation to climate change.

2. Objective 2: The population, economic agents, and the State conserve carbon reserves and contribute to the reduction of GHG emissions. The management indicators are the following:

a. Growth rate of GHG emissions below the GDP growth rate;

b. Carbon intensity of the economy;

c. Reduction of GHG emissions in all sectors, especially in those that emit the most GHG emissions;

d. Increase of carbon capture and net reduction of emissions in the forestry sector.

\section{Objectives and indicators of the National Biodiversity Strategy to 2021}

In its National Biological Diversity Strategy to 2021, the specialists of MINAM (2014) proposed the following strategic objectives and management indicators:

1. Strategic Objective SO1: To improve the state of biodiversity and maintain the integrity of the ecosystem services that it provides. The management indicators are the following:

$\checkmark$ Indicator 1.1: Percentage of the land area that is under some form of effective management of biodiversity;

$\checkmark \quad$ Indicator 1.2: Percentage of the marine area that is under some form of effective management of biodiversity;

$\checkmark \quad$ Indicator 2: Number of prepared conservation plans for species with initiated implementation;

$\checkmark$ Indicator 3: Number of evaluated programs for conservation and sustainable use of genetic diversity for species or groups of species for which we are the center of origin and/or diversification, as well as for their wild relatives.

2. Strategic Objective SO2: To increase the contribution of biodiversity to national development by improving the country's competitiveness and the equitable distribution of benefits. The management indicators are the following:

$\checkmark$ Indicator 4.1: Number of Remuneration Mechanisms for Ecosystem Services implemented;

$\checkmark$ Indicator 4.2: Number of competitive bio-businesses, preferably oriented to the bio-commerce model, that commercialize products of biodiversity at a national and international level with added value;

$\checkmark$ Indicator 5: Number of regulatory instruments implemented that are related to the Nagoya ABS Protocol.

3. Strategic Objective SO3: To reduce direct and indirect pressures for biological diversity and its ecosystem processes. The management indicators are the following:

$\checkmark$ Indicator 6: Percentage of the population that declares to have knowledge about the country's biodiversity;

$\checkmark \quad$ Indicator 7: National deforestation rate;

$\checkmark$ Indicator 8.1: Number of records of environmental events with an impact on biodiversity; 
$\checkmark$ Indicator 8.2: Number of regulatory mechanisms of threatened species, and updated mechanisms;

$\checkmark \quad$ Indicator 8.3: Number of regulatory mechanisms of invasive alien species.

4. Strategic Objective SO4: Strengthen the capacities of the three levels of government for the sustainable management of biodiversity. The management indicators are the following:

$\checkmark \quad$ Indicator 9.1: Number of regional governments that have strategies and action plans for the management of biodiversity in implementation;

$\checkmark \quad$ Indicator 9.2: Percentage of provincial and district municipalities that carry out activities within the framework of the respective strategy and regional biodiversity action plan.

5. Strategic Objective SO5: To improve knowledge and technologies for the sustainable use of biodiversity, as well as the revaluation of traditional knowledge linked to the biodiversity of indigenous peoples. The management indicators are the following:

$\checkmark \quad$ Indicator 10.1: Number of biodiversity research projects;

$\checkmark \quad$ Indicator 10.2: Percentage of annual increase in the number of traditional knowledge records;

$\checkmark$ Indicator 11: Number of native species for which knowledge of genetic wealth has increased, including its territorial distribution;

$\checkmark$ Indicator 12: Percentage of annual increase in the number of traditional knowledge registers.

6. Strategic Objective SO6: Strengthen the cooperation and participation of all sectors of the population in the governance of biological diversity. The management indicators are the following:

$\checkmark$ Indicator 13.1: Number of participatory governance agreements for biological diversity;

$\checkmark$ Indicator 13.2: Number of experiences of participatory governance of biological diversity;

$\checkmark$ Indicator 13.3: Number of public-private partnerships to promote the conservation and enhancement of biodiversity.

\section{The Proposal: Sustainable Land Management's Integrated Framework for Interventions (SLMIFI)}

Based on the literature reviewed, the Sustainable Land Management's Integrated Framework for Interventions (SLMIFI) was proposed as an integrated framework for the interventions of SLM in the countries with a national, regional, and local approach taking into account the biological diversity, the climate change, and the fight against desertification and drought.

\section{SLMIFI at the national level}

Considering the Peruvian National Strategy to Combat Desertification and Drought 2016-2030, the Peruvian National Strategy for Biological Diversity by 2021, and the Peruvian National Strategy on Climate Change, and by taking into account diverse previous studies and management instruments developed at national and international levels, the following objectives and management indicators for SLM are proposed (see figure 1): 


\section{GO}

To manage the land in a sustainable manner, improving the human development of the national population.

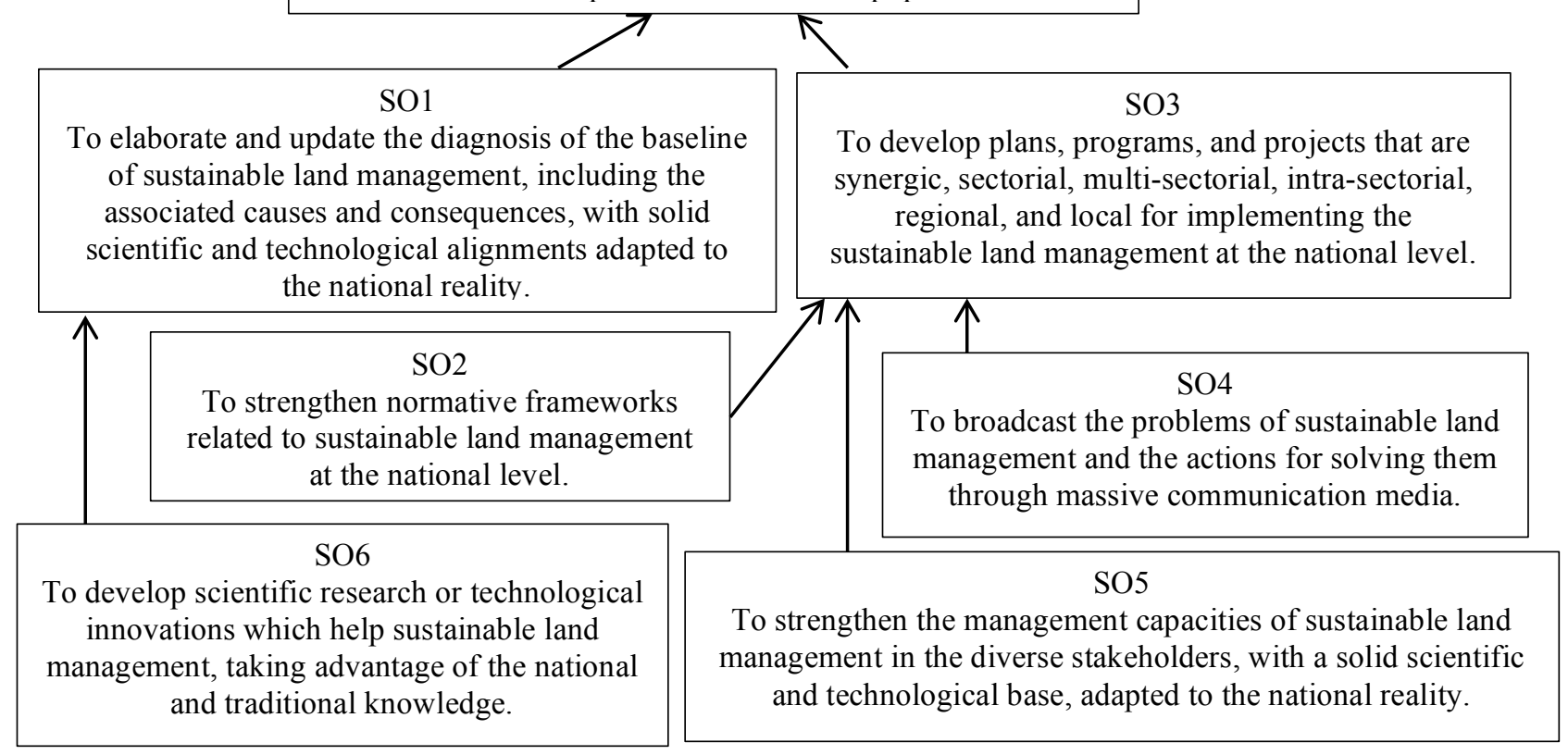

Figure 1. The general objective and the specific objectives of the SLM at the national level, according to SLMIFI.

1. General Objective $(G O)$ : To manage the land in a sustainable manner, improving the human development of the national population. The management indicators of the GO are the following:

$\checkmark$ IOG-1: Percentage of affected areas (in the terrestrial, marine, and aerial areas) in which interventions have been carried out for the recovery of desertification, land degradation, and the impact of drought, biological diversity, and the effects of climate change (MINAM, 2016; MINAM, 2014; United Nations, 2007);

$\checkmark \quad$ IOG-2: Percentage of areas (in the terrestrial, marine, and aerial areas) in which interventions have been implemented for the prevention of desertification, land degradation, and the impact of drought, biological diversity, and the effects of climate change (MINAM, 2016; United Nations, 2007);

$\checkmark \quad$ IOG-3: Increase in carbon stocks (soil and plant biomass) in the affected areas (MINAM, 2016; MINAM, 2015; United Nations, 2016; United Nations, 2007);

$\checkmark \quad$ IOG-4: Reduction in greenhouse gas emissions in the affected areas (MINAM, 2015);

$\checkmark$ IOG-5: Reduction in environmental pollutants in the affected areas (Basso \& Ritchie, 2015; MacLeod \& Moller, 2013; Sustainable Forestry Initiative, 2010);

$\checkmark$ IOG-6: Increase in net primary productivity of soils in the affected areas (MINAM, 2016; United Nations, 2016; Basso \& Ritchie, 2015; United Nations, 2007);

$\checkmark$ IOG-7: Reduction in the number of people affected by desertification, land degradation and drought, loss of biological diversity, and the effects of climate change, as a result of the 
interventions made (MINAM, 2016; Sustainable Forestry Initiative, 2010; United Nations, 2007);

$\checkmark$ IOG-8: Increase in the proportion of households living above the poverty line in the affected areas, as a result of the interventions carried out (MINAM, 2016; MINAM, 2015; United Nations, 2007);

$\checkmark$ IOG-9: Reduction in the proportion of the population that is below the minimum level of food energy consumption in the affected areas, as a result of the interventions made (MINAM, 2016; United Nations, 2007);

$\checkmark$ IOG-10: Reduction in the loss of human lives in the areas affected by the lack of SLM, as a result of the interventions carried out (MINAM, 2015);

$\checkmark$ IOG-11: Reduction in species losses in areas affected by the lack of SLM, as a result of the interventions made (United Nations, 2016; MINAM, 2014);

$\checkmark$ IOG-12: Increase in water availability (potable and non-potable, superficial and underground) in the areas affected by the lack of SLM, as a result of the interventions carried out (United Nations, 2016; MINAM, 2014; Chileshe et al., 2010).

\section{Specific Objectives:}

A. Specific Objective 1 (SO1): To elaborate and update the diagnosis of the baseline of the SLM, including the associated causes and consequences, with solid scientific and technological alignments adapted to the national reality. The management indicator is:

$\checkmark \quad$ IOE1-1: Percentage of regions that have developed and/or updated the baselines of the areas affected by desertification, land degradation, and drought, loss of biological diversity, and the effects of climate change (MINAM, 2016; MacLeod \& Moller, 2013; GEF, UNEP, \& FAO, 2013; Václavík et al., 2013; United Nations, 2007).

B. Specific Objective 2 (SO2): To strengthen normative frameworks related to SLM at the national level. The management indicators are as follows:

$\checkmark$ IOE2-1: Percentage of entities related to the reduction of desertification, land degradation, and the impact of drought, loss of biological diversity, and the effects of climate change, which have sufficient regulatory frameworks for effective participation (MINAM, 2016; United Nations, 2007);

$\checkmark$ IOE2-2: Percentage of threatened species for which regulatory mechanisms have been developed (MINAM, 2014);

$\checkmark$ IOE2-3: Percentage of invasive or harmful species for which regulatory mechanisms have been developed (MINAM, 2014; MacLeod \& Moller, 2013).

C. Specific Objective 3 (SO3): To develop plans, programs, and projects that are synergic, sectorial, multi-sectorial, intra-sectorial, regional, and local for implementing SLM at the national level. The management indicators are the following:

$\checkmark$ IOE3-1: Percentage of related entities that have plans, programs, and projects that are synergistic, multi-sectorial, intra-sectorial, regional, and local to reduce desertification, land degradation, and the impact of drought, loss of biodiversity, and effects of climate change (MINAM, 2016); 
$\checkmark$ IOE3-2: Percentage of progress in the execution of plans, programs, and projects that are synergistic, multi-sectorial, intra-sectorial, regional, and local to reduce desertification, land degradation, and the impact of drought, loss of biological diversity, and the effects of climate change (MINAM, 2016; MINAM, 2014);

$\checkmark$ IOE3-3: Percentage of budget execution of plans, programs, and projects to combat desertification, land degradation, and the impact of drought, loss of biological diversity, and the effects of climate change (MINAM, 2016; MINAM, 2015);

$\checkmark$ IOE3-4: Percentage of plans, programs, and projects completed and evaluated that are synergistic, multi-sectorial, intra-sectorial, regional, and local to reduce desertification, land degradation, and the impact of drought, loss of biodiversity, and effects of climate change (MINAM, 2016, MINAM, 2014);

$\checkmark$ IOE3-5: Percentage of interventions in which compensation mechanisms for ecosystem services have been implemented (MINAM, 2014);

$\checkmark$ IOE3-6: Percentage of progress in the implementation and/or updating of a knowledge base and an information system for SLM (MINAM, 2016; MINAM, 2014; Chileshe et al., 2010).

D. Specific Objective 4 (SO4): To broadcast the problems of SLM and the actions for solving them through massive communication media. The management indicators are the following:

$\checkmark$ IOE4-1: Percentage of mass communication media that disseminate the problem and actions to reduce desertification, land degradation, and the impact of drought, loss of biological diversity, and the effects of climate change, periodically (MINAM, 2016);

$\checkmark$ IOE4-2: Percentage of the population that knows the problems and actions to reduce desertification, land degradation, and the impact of drought, loss of biological diversity, and the effects of climate change (MINAM, 2016; MINAM, 2015; MINAM, 2014; Sustainable Forestry Initiative, 2010).

E. Specific Objective 5 (SO5): To strengthen the management capacities of SLM in the diverse stakeholders, with a solid scientific and technological base, adapted to the national reality. The management indicators are the following:

$\checkmark$ IOE5-1: Percentage of government entities related to the reduction of desertification, land degradation, and the impact of drought, the loss of biological diversity, and the effects of climate change, in which its key officials and servants have received training for their effective participation (MINAM, 2016; MINAM, 2014; Sustainable Forestry Initiative, 2010);

$\checkmark$ IOE5-2: Percentage of non-governmental entities related to the reduction of desertification, land degradation, and the impact of drought, loss of biodiversity, and the effects of climate change, in which its officials or key workers have received training for their effective participation (MINAM, 2016);

$\checkmark$ IOE5-3: Percentage of people associated with the theme of desertification, land degradation, and drought, loss of biological diversity, and the effects of climate change, who have received training on this subject (MINAM, 2016; MINAM, 2015; Sustainable Forestry Initiative, 2010).

F. Specific Objective 6 (SO6): To develop scientific research or technological innovations which help SLM, taking advantage of the national and traditional knowledge. The management indicators are the following: 
$\checkmark$ IOE6-1: Percentage of progress in the development of scientific research and technological innovations associated with SLM (MINAM, 2016; MINAM, 2015; MINAM, 2014);

$\checkmark$ IOE6-2: Percentage of progress in achieving the goal of publications in indexed journals associated with SLM (MINAM, 2016);

$\checkmark$ IOE6-3: Percentage of progress in the development of scientific research and technological innovations associated with SLM considering the national and traditional knowledge (Critchley \& Radstake, 2017; MINAM, 2016; MINAM, 2015; MINAM, 2014);

$\checkmark$ IOE6-4: Percentage of progress in achieving the goal of publications in indexed journals associated with SLM considering the national and traditional knowledge (Critchley \& Radstake, 2017; MINAM, 2016).

\section{SLMIFI at regional or local level}

The phases for the development of an SLM intervention (see Figure 2) at the regional or local level are as follows:

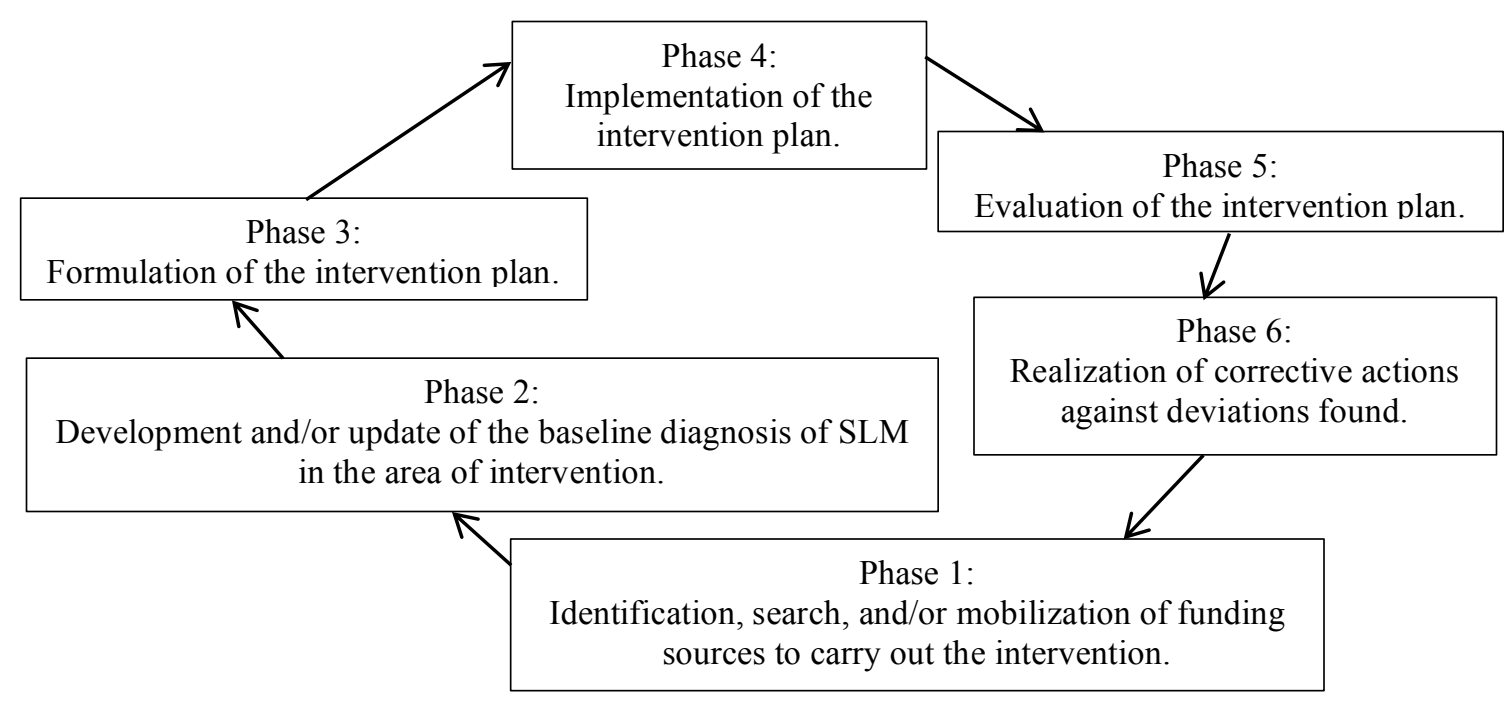

Figure 2. Phases of SLMIFI for the development of an SLM intervention at the regional or local level.

1. Phase 1: Identification, search and/or mobilization of funding sources to carry out the intervention. It is necessary to identify the available or accessible sources of funds to perform the intervention related to SLM: ordinary resources, directly collected resources, funds from the national public investment system, resources of international technical cooperation, retribution for ecosystem services, among others.

2. Phase 2: Development and/or update of the baseline diagnosis of SLM in the area of intervention. For each affected area, the status of the following aspects associated with SLM must be diagnosed (MINAM, 2014; Václavík et al., 2013; MacLeod \& Moller, 2013; Chileshe et al., 2010; Matta, 2008):

$\checkmark \quad$ With respect to land ownership: (a) conflicts over land tenure, (b) expropriation conflicts, (c) restoration of native communities, and (d) loss of religious/cultural areas;

$\checkmark \quad$ With respect to land management: (a) land governance, (b) non-productive land uses, (c) urban expansion, (d) energy sources, (e) overgrazing, and (f) reduction of the rural population; 
$\checkmark \quad$ With respect to the characteristics of the land: (a) contamination and degradation of pastures, soil, water (surface and underground), and air; (b) deforestation and loss of native forests; (c) pests, diseases, and weeds; (d) soil quality, net primary soil productivity, carbon sequestration, nutrients, erosion, soil salinity, and soil acidity; (d) quality, productivity, sources and availability of water; (e) diversity, periodicity, and crop yields; and (f) temperature, emissions of greenhouse gases, precipitation and evapotranspiration, among others.

The diagnosis must include the elaboration of geographic base maps with the characteristics of the land, land management, and land ownership, together with social, economic, political, and legal factors, such as: population, educational level of the population, poverty levels of the population, economic activities, gross domestic product, political stability (Václavík et al., 2013; GEF, UNEP, \& FAO, 2013), normative framework for SLM in the areas of intervention, as well as the causes and consequences of the associated problem, for obtaining a diagnostic base map of the area of the intervention (GEF, UNEP, \& FAO, 2013).

3. Phase 3: Formulation of the intervention plan. In this phase, the intervention plan must be formulated in accordance with the policies and procedures of the organization that will execute it or in accordance with the policies and procedures of the entity that will approve the financing. It is suggested to take into account the aspects described in the section titled "Structure of the Plan for an SLM Intervention at Regional or Local Level". The plan must be formulated by taking into account the participation of the various stakeholder groups, as well as the suggested phases of this section.

4. Phase 4: Implementation of the intervention plan. In this phase, the intervention must be implemented in accordance with what was planned, taking into account the relevant management indicators for the intervention areas based on the management indicators proposed in the framework at the national level.

5. Phase 5: Evaluation of the intervention plan. The evaluation of the intervention plan must be done at least quarterly, so that deviations can be identified with respect to what was planned in a timely manner. For this evaluation, it is essential to calculate the management indicators and contrast the results obtained with the results expected, so that deviations can be identified and corrective actions planned for the future.

6. Phase 6: Realization of corrective actions against deviations found. After the evaluation of the intervention plan and the identification of deviations, the pertinent corrective actions must be carried out to tackle the deviations found, which must be done in conjunction with the groups of stakeholders interested in the intervention, so that the necessary consensus is obtained with respect to their implementation.

\section{Structure of the Plan for an SLM Intervention at Regional or Local Level}

The components of the plan for an SLM intervention at regional or local level are the following:

\section{Diagnosis of SLM in the area of intervention}

a. Areas that have been affected in their biological diversity, affected by climate change, or affected by desertification, land degradation, and drought. The geographical, population, social, economic, and political characteristics, among other aspects of the affected areas, should be specified here, taking into account the following information: (i) affected provinces, (ii) affected districts, (iii) type of population, communities or economic sectors affected, (iv) number of people affected, (v) land ownership, (vi) land 
management, (vii) characteristics of the land, (viii) causes for which they were affected, and (ix) consequences after being affected.

b. Areas that would be affected in their biological diversity by climate change or by desertification, land degradation, and drought. The geographical, population, social, economic, and political characteristics, among other aspects of the areas that would be affected, should be specified here, taking into account the following information: (i) provinces that would be affected, (ii) districts that would be affected, (iii) type of population, communities, or economic sectors that would be affected, (iv) land ownership, (v) land management, (vi) characteristics of the land, (vii) number of people who would be affected, (viii) causes for which they would be affected, and (ix) consequences after being affected.

c. Projects for SLM in affected areas. The characteristics of the projects in the affected areas should be specified here, taking into account the following information: (i) provinces that would benefit, (ii) districts that would benefit, (iii) type of population, communities, or economic sectors that would benefit, (iv) number of people who would be benefited, (v) title of the project, (vi) amount of the project, (vii) funding source, (viii) status of the projects (proposals, in execution and completed), and (ix) objectives, scope, and stages, among other relevant aspects.

d. Projects for SLM in areas that would be affected. The characteristics of the projects in the areas that would be affected should be specified here, taking into account the following information: (i) provinces that would benefit, (ii) districts that would benefit, (iii) type of population, communities, or economic sectors that would benefit, (iv) number of people who would be benefited, (v) title of the project, (vi) amount of the project, (vii) funding source, (viii) status of projects (proposed, in execution and completed), and (ix) objectives, scope, and stages, among other relevant aspects.

e. Regulatory framework related to biological diversity, actions against climate change, and the fight against desertification, land degradation and drought, as well as other aspects related to SLM that are applicable to the areas of intervention. The international, national, and regional normative framework, related to the fight against damage to biological diversity, fight against climate change, and the fight against desertification, land degradation, and drought, as well as other applicable normative frameworks in the intervention area, and aspects associated with SLM (ownership of land, land management, and land characteristics) for the affected areas and for the areas that would be affected should be explained here.

\section{General objective, specific objectives, indicators, and expected results of the SLM intervention}

The general objective, the specific objectives, the indicators, and the results of the SLM intervention should be placed here. Contributions to the achievement of national, regional, and local objectives should be taken into account, depending on the scope of the intervention.

3. Proposed projects related to SLM. The profiles of the proposed projects as part of the regional action plan, related to the protection and conservation of biological diversity, the fight against climate change, the fight against desertification, land degradation, and drought in the region should be presented here, as well as other aspects related to SLM, with a planning horizon of at least 15 years. These projects may include diagnosis, prevention, conservation, rehabilitation, monitoring and control, research, dissemination, and the improvement of the related regulatory frameworks. The following aspects must be included for each project (Project Management Institute, 2017): 
a. The scope management. It should include the components of the final result that is expected at the end of the project.

b. The management of time. The execution schedules (Gantt diagrams) of the project must be specified.

c. The management of costs. Investments and expenses must be specified, as well as their sources of financing: ordinary resources, resources directly collected, funds from the national system of public investment), international cooperation, or compensation mechanisms for ecosystem services.

d. Quality management. The rules that must be taken into account for the deployment of the projects, as well as the activities for the following processes, must be specified:

i. Quality assurance: activities to give confidence that the project will be carried out in accordance with current regulations and the expected results. Among these activities we have: preparation of plans, development of policies, elaboration of procedures, and training.

ii. Quality control: activities to verify that the execution of each stage of the project has met the specifications of the scope. Among these activities we have: verifications (checklists of compliance with the specifications), validations (checklists with the beneficiaries of the project regarding the satisfaction of their needs related to the project) and joint reviews (revisions jointly carried out by the regional government authorities and the community or the supervisory or auditing entities).

e. The management of human resources: activities associated with recruitment, selection, training, performance evaluation, compensation, and social welfare of project staff.

f. The management of communications: activities to timely communicate the various aspects of the project to project stakeholders.

g. Risk management: activities associated with the identification of risks, qualitative analysis of risks, quantitative analysis of risks, determination of the risks that we are going to protect against, measures to mitigate risks, and allocation of resources for the mitigation of risks.

h. The management of acquisitions: activities for the purchase or contracting of the goods or services that will be required in the project.

i. The management of project stakeholders. It includes: identification of project stakeholders, planning of stakeholder management, management of stakeholder participation, and control of stakeholder participation.

The proposed projects and the improvements in human and financial resources should be updated in the concerted development plan, in the institutional strategic plan, and in the institutional operational plan at the regional or local level. It must also take into account the action alignments that are applicable, in a synergistic manner.

4. Human Resources. The human resources that will be needed to carry out the successful implementation of operations and projects of the SLM intervention should be placed here. It should be noted that the human resources that will participate in the project correspond to those belonging to each of the groups of stakeholders interested in the project. 
5. Budget. The budget for investments and expenditures that will be needed to successfully implement the operations and projects of the SLM intervention should be placed here.

\section{Discussion and Conclusion}

Diverse frameworks for SLM were proposed previously to SLMIFI; however, those frameworks did not have a holistic approach towards fighting against climate change, the conservation of biological diversity, desertification and drought. As can be appreciated from the literature, the conditions for competitiveness must be sustainable; however, SLM is not part of the pillars of the indexes related to competitiveness, a situation that could appear unsustainable. Hence, it becomes imperative for future international, national, or regional competitiveness indexes to include SLM as one of the most important pillars or factors for evaluating the competitiveness of the countries and some of the indicators must be the following: the investment in SLM interventions, the reduction of land degradation, and the improvement of the conditions of the natural resources, among other important indicators of SLM, considering also the regional level for regional competitiveness indexes inside the countries.

SLMIFI is an integrated framework for interventions of SLM at national, regional, and local levels. Some managerial implications are the urgent needs for integrating the management structures or global conventions in the United Nations (UNCCD, UNFCCC, and UNCBD) and the respective areas in the governments such as: international organizations of countries, ministries of environment or similar institutions, regional governments, local governments, and the nongovernmental organizations that manage the fight against climate change, the conservation of the biodiversity, and the fight against desertification, land degradation, and drought as a whole, considering SLMIFI or other future integrated frameworks for interventions of SLM at local, regional, national, and international levels. Additionally, pre-degree and post-degree environmental management programs in universities must include courses about how to integrate SLMIFI or other comprehensive frameworks or methodologies in SLM projects. It is important to notice also that future regulations at diverse levels must include a holistic vision of SLM in environmental projects, accompanied by integrated frameworks such as SLMIFI or other comprehensive frameworks.

Some limitations of SLMIFI are as follows: (a) the generalization of biological species in grouped indicators; nonetheless, considering the diverse reality of every country, the adaptation of the indicators in view of the species might be necessary; (b) the application of SLMIFI could require a holistic vision that environmental project managers might not have; and (c) the lack of integration of SLMIFI with disaster recovery management and the resilience of countries and regions. Finally, future avenues for research could include: (a) the validation of SLMIFI with real projects for improving it and taking into account the critical success factors in applying it; (b) the evaluation of the results of SLM interventions with and without the application of SLMIFI and comparing SLMIFI with other comprehensive frameworks or methodologies; (c) the evaluation of the results of the applications of the improvements of SLMIFI adapted according to the realities of diverse countries and regions; and (d) the improvement and validation of SLMIFI considering disaster recovery management and the resilience of countries and regions.

\section{References}

Abatzoglou, J. T. \& Williams, A. P. (2016). Impact of Anthropogenic Climate Change on Wildfire across Western US Forests. PNAS, 113(42), 11770-11775.

Adelle, C., Delputte, S., De Roeck, F., \& Nicholson, S. (2018). Environmental Instruments in Development Cooperation: Promoting Better Development and Environmental Outcomes? In C. Adelle, K. 
Biedenkopf, \& D. Torney (Eds.), European Union External Environmental Policy: Rules, Regulation and Governance Beyond Borders (pp. 81-101). Cham, Switzerland: Palgrave Macmillan.

Basso, B. \& Ritchie, J. T. (2015). Simulating crop growth and biogeochemical fluxes in response to land management using the SALUS model. In S. K. Hamilton, J. E. Doll, \& G. P. Robertson (Eds.), The Ecology of Agricultural Landscapes: Long-Term Research on the Path to Sustainability (pp. 343-375). New York, NY: Oxford University Press.

Biedenkopf, K., Torney, D., \& Adelle, C. (2018). Conclusions. In C. Adelle, K. Biedenkopf, \& D. Torney (Eds.), European Union External Environmental Policy: Rules, Regulation and Governance Beyond Borders. Palgrave Macmillan.

Bryan, E., Ringler, C., Okoba, B., Koo, J., Herrero, M., \& Silvestri, S. (2013). Can agriculture support climate change adaptation, greenhouse gas mitigation and rural livelihoods? Insights from Kenya. Climatic Change, 118(1), 151-165.

Chileshe, P., Oladapo, O., Shalaby, H., Telahigue, N., \& Sarr, L. (2010). Sustainable Land Management in The Gambia - Project Appraisal Report. Published on $20^{\text {th }}$ May 2010. Retrieved from http://www.afdb.org/fileadmin/uploads/afdb/Documents/Project-and-Operations/Gambia__Sustainable_Land_Management_-_Appraisal_Report.pdf

Critchley, W. \& Radstake, F. (2017). Sustainable Land Management in Asia: Introducing the Landscape Approach. Mandaluyong, Philippines: Asian Development Bank.

Delreux, T. (2018). Multilateral Environmental Agreements: A Key Instrument of Global Environmental. In C. Adelle, K. Biedenkopf, \& D. Torney (Eds.), European Union External Environmental Policy: Rules, Regulation and Governance Beyond Borders (pp. 19-38). Cham, Switzerland: Palgrave Macmillan.

Despotovic, D., Cvetanovic, S., Nedic, V., \& Despotovic, M. (2016). Economic, Social and Environmental Dimension of Sustainable Competitiveness of European Countries. Journal of Environmental Planning and Management, 59(9), 1656-1678.

D’Odorico, P., Bhattachan, A., Davis, K. F., Ravi, S., \& Runyan, C. W. (2013). Global Desertification: Drivers and Feedbacks. Advances in Water Resources, 51(1), 326-344.

Dudey, N., Attwood, S., Goulson, D., Jarvis, D., Bharucha, Z. P., \& Pretty, J. (2017). How should conservationists respond to pesticides as a driver of biodiversity loss in agroecosystems? Biological Conservation, 209(1), 449-453.

Dupont, C., Oberthür, S., \& Biedenkopf, K. (2018). Climate Change: Adapting to Evolving Internal and External Dynamics. In C. Adelle, K. Biedenkopf, \& D. Torney (Eds.), European Union External Environmental Policy: Rules, Regulation and Governance Beyond Borders (pp. 105-124). Cham, Switzerland: Palgrave Macmillan.

GEF, UNEP, \& FAO (2013). Land Degradation Assessment in Drylands - Questionnaire for mapping land degradation and sustainable land management $(Q M)$ version 2. Retrieved from http://www.fao.org/3/a-i3240e.pdf

Hisano, M., Searle, E. B., \& Chen, H. Y. H. (2018). Biodiversity as a solution to mitigate climate change impacts on the functioning of forest ecosystems. Biological Reviews, 93(1), 439-456.

Kettunen, M. (2018). Biodiversity: Strong Policy Objectives Challenged by Sectoral Integration. In C. Adelle, K. Biedenkopf, \& D. Torney (Eds.), European Union External Environmental Policy: Rules, Regulation and Governance Beyond Borders (pp. 147-165). Cham, Switzerland: Palgrave Macmillan.

MacLeod, C. J. \& Moller, H. (2013). Environmental Monitoring for Sustainable Land Management in New Zealand's production landscapes. The NZ Sustainability Dashboard Research Report 13/10. New Zeland: Argos. 
Maisharou, A., Chirwa, P. W., Larwanou, M., Babalola, F., \& Ofoegbu, G. (2015). Sustainable Land Management Practices in the Sahel: Review of Practices, Techniques and Technologies for Land Restoration and Strategy for Up-Scaling. International Forestry Review, 17(53), 1-19.

Masih, J. (2010). Causes and Consequences of Global Climate Change. Archives of Applied Science Research, 2(2), 100-108.

Matta, A. (2008). Sustainable Development Indicators for Land Use in Santiago, Chile. Master's Thesis in Applied Environmental Measurement Techniques. Chalmers University of Technology. Retrieved from http://publications.lib.chalmers.se/records/fulltext/68706.pdf

Ministry of Environment of Peru - MINAM. (2014). Estrategia Nacional de Diversidad Biológica al 2021 - Plan de Acción 2014-2018 [National Strategy of Biological Diversity 2014-2018]. Retrieved from http://sinia.minam.gob.pe/download/file/fid/40740

Ministry of Environment of Peru - MINAM. (2015). Estrategia Nacional ante el Cambio Climático 2015 [National Strategy for Climate Change]. Retrieved from http://www.minam.gob.pe/wpcontent/uploads/2015/09/ENCC-FINAL-250915-web.pdf

Ministry of Environment of Peru - MINAM. (2016). Estrategia Nacional de Lucha Contra la Desertificación y la Sequía 2016-2030 [National Strategy against Desertification and Drought 20162030]. Recuperado de http://www.minam.gob.pe/wp-content/uploads/2016/07/LUCHA-CONTRALA-DESERTIFICACION-Y-LA-SEQUIA-2016-2030.pdf

PBL Netherlands Environmental Assessment Agency. (2014). GlobCover Database. Published at April $24^{\text {th }}, 2014$. Retrieved from http://models.pbl.nl/image/index.php/GlobCover_database

Porter, M. E., Stern, S., \& Green, M. (2017). Social Progress Index 2017. Retrieved from https:/www.socialprogressindex.com/assets/downloads/resources/en/English-2017-Social-ProgressIndex-Findings-Report_embargo-d-until-June-21-2017.pdf

Project Management Institute. (2017). Project Management Body of Knowledge (6 $6^{\text {th }}$ ed.). Pennsylvania: Project Management Institute.

Rodríguez De Luque, J. J., Gonzalez, C., Gourdji, S., Mason-D’Croz, D., Obando-Bonilla, D., Mesa-Diez, J., \& Prager, S. D. (2016). Impactos socioeconómicos del cambio climático en América Latina y el Caribe: 2020-2045 [Socio-Economic Impacts of Climate Change in Latin America and the Caribbean: 2020-2045]. Cuadernos de Desarrollo Rural, 13(78), 11-34.

Schwab, K. (2017). The Global Competitiveness Report 2017-2018. Geneva, Switzerland: World Economic Forum.

Sustainable Forestry Initiative. (2010). SFI 2010-2014 Standard. Retrieved from http://www.sfiprogram.org/files/pdf/Section2_sfi_requirements_2010-2014.pdf

United Nations. (1992a). United Nations Framework Convention on Climate Change. Retrieved from https://unfccc.int/resource/docs/convkp/conveng.pdf

United Nations. (1992b). Convention on Biological Diversity. Retrieved from https://www.cbd.int/doc/legal/cbd-en.pdf

United Nations. (1994). Intergovernmental Negotiating Committee for the Elaboration of an International Convention to Combat Desertification in Those Countries Experiencing Serious Drought and/or Desertification, Particularly in Africa. Retrieved from http://www.ifrc.org/docs/idrl/I223EN.pdf

United Nations. (2007). Decision 3/COP.8: The 10-year strategic plan and framework to enhance the implementation of the Convention (2008-2018). Retrieved from https://www2.unccd.int/sites/default/files/inline-files/3cop8eng.pdf

United Nations. (2016). Report of the Conference of the Parties on its twelfth session, held in Ankara from 12 to 23 October 2015 - Part two: Action taken by the Conference of the Parties at its twelfth session. Published at January 21th, 2016. Retrieved from 
https://www2.unced.int/sites/default/files/sessions/documents/ICCD_COP12_20_Add.1/20add1eng.pd $\mathrm{f}$ \#page $=8$

United Nations. (2017). Scientific Conceptual Framework for Land Degradation Neutrality: A Report of the Science-Policy Interface. Bonn, Germany: United Nations.

United Nations. (2018). Second Annual Report on Regional Progress and Challenges in relation to the 2030 Agenda for Sustainable Development in Latin America and the Caribbean. Retrieved from https://repositorio.cepal.org/bitstream/handle/11362/43439/S1800145_en.pdf?sequence=4\&isAllowed $=\mathrm{y}$

Václavík, T., Lautenbach, S., Kuemmerle, T., \& Seppelt, R. (2013). Mapping global land system archetypes. Global Environmental Change, 1180. Retrieved from http://nachhaltigeslandmanagement.de/uploads/tx_t3documents/00038-

Vaclavik_Mapping_global_land_system_archetypes.pdf

WOCAT. (2010). A Framework for Documentation and Evaluation of Sustainable Land Management: Watershed Management. Bern, Switzerland: WOCAT.

World Bank. (2008). Sustainable Land Management Sourcebook. Washington D.C.: World Bank.

World Bank. (2018). Doing Business 2018: Reforming to Create Jobs. Retrieved from http://www.doingbusiness.org/ /media/WBG/DoingBusiness/Documents/AnnualReports/English/DB2018-Full-Report.pdf

Yale University. (2018). 2018 Environmental Performance Index. Retrieved from https://epi.envirocenter.yale.edu/downloads/epi2018policymakerssummaryv01.pdf

\section{Author Note}

The author would like to thank the special issue editor, the language editor of the journal, and the anonymous referees for their valuable feedback on the previous versions of this paper.

Correspondence concerning this article should be addressed to Emigdio Alfaro, CENTRUM Católica Graduate Business School (CCGBS), Pontificia Universidad Católica del Perú (PUCP), Calle Daniel Alomía Robles 125-129, Los Alamos de Monterrico, Santiago de Surco, Lima, Lima 33, Peru. Email: emigdio.alfaro@pucp.pe

\section{Biographical Note}

Emigdio Alfaro is a professor and researcher at CENTRUM Católica Graduate Business School, Pontificia Universidad Católica del Perú (PUCP), Lima, Peru. He is a Doctor of Education from the Universidad Privada Norbert Wiener of Peru; Doctor (c) in Business Administration, MBA, and Master of Philosophy from the Maastricht School of Management, The Netherlands; Ph.D. (c) in Strategic Management of Businesses and Master in Strategic Management from CENTRUM Católica Graduate Business School; and Informatics Engineer from PUCP. He has worked as a manager, consultant, and auditor in diverse organizations from diverse sectors, in the areas of strategic management, process management, project management, implementation of quality norms, and information technology management. 